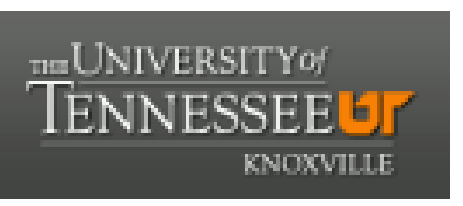

University of Tennessee, Knoxville

TRACE: Tennessee Research and Creative

Exchange

September 2011

\title{
In Defense of the Substance-Procedure Dichotomy
}

Jennifer S. Hendricks

University of Tennessee College of Law, jennysusan@gmail.com

Follow this and additional works at: https://trace.tennessee.edu/utk_lawpubl

Part of the Law Commons

\section{Recommended Citation}

Hendricks, Jennifer S., "In Defense of the Substance-Procedure Dichotomy" (2011). College of Law Faculty Scholarship.

https://trace.tennessee.edu/utk_lawpubl/44

This is brought to you for free and open access by the Law at TRACE: Tennessee Research and Creative Exchange. It has been accepted for inclusion in College of Law Faculty Scholarship by an authorized administrator of TRACE:

Tennessee Research and Creative Exchange. For more information, please contact trace@utk.edu. 


\title{
IN DEFENSE OF THE SUBSTANCE-PROCEDURE DICHOTOMY
}

\author{
JENNIFER S. HENDRICKS †
}

\begin{abstract}
John Hart Ely famously observed, "We were all brought up on sophisticated talk about the fluidity of the line between substance and procedure," but for most of Erie's history, the Supreme Court has answered the question "Does this state law govern in federal court?" with a "yes" or a "no." Beginning, however, with Gasperini v. Center for Humanities, and continuing with Semtek v. Lockheed and the dissenting opinion in Shady Grove v. Allstate, a shifting coalition of justices has pursued a third path. Instead of declaring state law applicable or inapplicable, they have claimed for themselves the prerogative to fashion law that purportedly accommodates the interests of both sovereigns. With the cover of an intellectual critique of the substance-procedure dichotomy, the Court has thus embarked on a new phase of Erie doctrine, a phase that replaces "yes" or "no" with "Let's see what we can work out."
\end{abstract}

This Article adds a new level of critique to the chorus of criticism that has already been directed at these opinions. It argues that the new enterprise and its blurring of the substance-procedure dichotomy are based on a misguided aspiration to accommodate state substantive policies at the expense of federal procedure.

Descriptively, in order to have a dichotomy, it is necessary to have two poles. This Article therefore demonstrates that the distinction between substance and procedure is appropriately represented by a single-dimensional spectrum. Part of what the Court has done wrong is to ignore this linear relationship by insisting, for

$\dagger$ Associate Professor, University of Tennessee College of Law. For generously taking the time to give helpful feedback on an earlier draft of this Article, thanks are due to Steve Burbank, Sergio Campos, Kevin Clermont, Robert Condlin, Judy Cornett, Thomas Main, Martin Redish, Tom Rowe, Jay Tidmarsh, and Patrick Woolley. Thanks also to Jamelle Sharpe and the University of Illinois College of Law for hosting the Junior Faculty Federal Courts Workshop at which this Article received helpful comments from Scott Dodson, Charlton Copeland, Tara Grove, Sam Jordan, Abbe Gluck, Matthew Hall, Lumen Mulligan, and others; and to the participants in the junior faculty workshop hosted at the Washington University School of Law by Rebecca Hollander-Blumoff. 
example, in Semtek, that res judicata is "too substantive" to be addressed in the Federal Rules yet procedural enough to be governed by federal common law under the Rules of Decision Act. In addition, given the linearity of substance and procedure, one could imagine the distinction either as a dichotomy of black and white, with every legal rule falling into one category or the other, or as a spectrum of gray, with many or even most legal rules falling in the mushy middle. Descriptively, of course, the latter view is more accurate. This Article argues, however, that the Court should nevertheless classify each one as black or white, rather than attempt to accommodate both its procedural and its substantive aspects.

This Article offers two reasons for preferring the black-white approach. First, the governing statutes contemplate a dichotomy between substance and procedure, and the Court is not authorized to use the ambiguity in that distinction to replace the statutory scheme with its own discretionary treatment of state law. Second, eschewing Phase Three and returning to the black-white approach would promote democratic transparency in the states. Specifically, in addition to traditional Erie concerns about judicial lawmaking, Congress has set a policy of establishing a uniform body of transsubstantive procedural law. State legislators know this, and there is nothing wrong with federal courts expecting them to act accordingly. If they, as Representative Dingell famously offered, prefer to manipulate procedure in order to undermine the substantive rights they purport to have created, the threat of fixed procedures in diversity could and should restrain them. Too often, the Supreme Court treats legislative enactments as fixed, so that the game begins when the litigants start their forum shopping. The game begins earlier, in the legislature, and the Court's ad hoc, accommodating approach to state law in Erie's third phase creates the wrong incentives for that game. 


\section{Table of Contents}

Introduction

I. The Three Phases of Erie .......................................................... 8

A. Phase One: Deference to the States ..................................... 9

B. Phase Two: The Imperial Rules........................................ 13

C. Phase Three: A Third Way to Nowhere .............................. 18

1. Gasperini v. Center for the Humanities ..................... 19

2. Semtek v. Lockheed ................................................ 21

3. Shady Grove v. Allstate ............................................. 23

4.

II. What's Wrong With the Third Way.......................................... 27

A. The Chorus of Criticism ................................................... 27

B. The Supreme Court Should Not Freelance on Choiceof-Law Questions ............................................................ 29

1. The Trouble With Semtek: The Supreme Court's Inherent Powers Cannot Exceed the Power of the Court and Congress Acting Together.......................... 30

2. The Trouble With Gasperini: The RDA Does Not Authorize a Body of Federal Common Law.............. 39

C. The REA and the Scope of State Legislative Authority ..... 41

1. Echoes of the First Two Phases ................................. 42

2. Separating Substance and Procedure to Improve State Lawmaking .................................................... 43

III. Ending Phase Three ................................................................ 54

A. The Phase-Three Approach Has No Traction in the Lower Courts ................................................................... 55

B. Containing Semtek ......................................................... 55

C. Containing Gasperini ..................................................... 59

D.

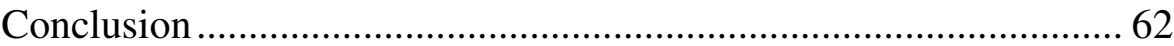


In the last fifteen years, the Supreme Court has been taking legal realism a bit too seriously. "We were all brought up on sophisticated talk about the fluidity of the line between substance and procedure," "but for many years, when presented with a thorny problem of vertical choice of law, the Supreme Court hemmed and hawed about the subtleness of the distinction-and picked one. Ultimately, a decision had to be made; either the federal courts would follow a particular state law in diversity cases or they would not.

In the First Phase of Erie, ${ }^{2}$ state law was ascendant and usually deemed binding. ${ }^{3}$ In the Second Phase, after Hanna v. Plumer, ${ }^{4}$ the Federal Rules reigned supreme, sweeping aside state laws in or near their path. ${ }^{5}$ In both phases, the Supreme Court's decisions sometimes strained credulity. They did, however, perform the function of answering the question "Does this state law govern in federal court?" with a "yes" or a "no." Beginning with Gasperini v. Center for Humanities, ${ }^{6}$ however, a shifting coalition of justices has pursued a third path, declaring state law neither wholly applicable nor wholly inapplicable. Instead, they have claimed for themselves the prerogative to fashion law that purportedly accommodates the interests of both sovereigns. ${ }^{7}$ With the cover of an intellectual critique of the substance-procedure dichotomy, this new approach represents a nascent Third Phase of the Erie doctrine, which would replace "yes" or "no" with "Let's see what we can work out."

This new venture-so far, Gasperini, Semtek, ${ }^{8}$ and, most recently, four or five justices in Shady Grove ${ }^{9}$ - has been the object

\footnotetext{
${ }^{1}$ John Hart Ely, The Irrepressible Myth of Erie, 87 HARV. L. REV. 693, 724 (1974).

${ }^{2}$ Erie R.R. v. Tompkins, 304 U.S. 64 (1938).

${ }^{3}$ See infra, Part I.A.

${ }^{4} 380$ U.S. 460 (1965).

${ }^{5}$ See infra, Part I.B. An exception during this Phase was Walker v. Armco Steel Corp., 446 U.S. 740 (1980), which adhered to a prior Phase One decision deferring to state law. See infra, note 67.

${ }^{6} 518$ U.S. 415 (1996).

${ }^{7}$ See infra, Part I.C.

${ }^{8}$ Semtek Int'1 Inc. v. Lockheed Martin Corp., 531 U.S. 497 (2001).
} 
of "a chorus of academic criticism."10 Most of this criticism focuses on problems of administrability, lack of adequate guidance to lower courts, and the continuing absurdity of reading a Federal Rule to mean one thing in federal cases and another in diversity. ${ }^{11}$

This Article adds a new level of critique. It argues that the Phase-Three approach and its blurring of the substance-procedure dichotomy are inappropriate uses of federal judicial power and are based on a misguided aspiration to accommodate state substantive policies at the expense of federal procedure. This thesis includes both a descriptive and a prescriptive claim.

Descriptively, in order to have a dichotomy, it is necessary to have two poles. This Article therefore demonstrates that the distinction between substance and procedure is appropriately represented by a single-dimensional spectrum. That is, even though there are several different ways of making the distinction-the Rules of Decision Act ("RDA") approach, ${ }^{12}$ the Rules Enabling Act ("REA") approach, ${ }^{13}$ the inherent powers approach ${ }^{14}$ - the tests for

${ }^{9}$ Shady Grove Orthopedic Assoc. v. Allstate Insur. Co., _ U.S. _, 130 S.Ct. 1431 (2010). The four dissenters in Shady Grove used a Phase-Three approach, while the lead opinion, joined in full by four justices, used an aggressive version of the Phase-Two approach. Justice Stevens joined parts of the lead opinion and wrote a separate concurrence that appeared to agree with the dissenters' approach in at least some respects, despite reaching a different conclusion. See infra, Part I.C.3. ${ }^{10}$ Earl C. Dudley \& George Rutherglen, Deforming the Federal Rules: An Essay On What's Wrong With the Recent Erie Decisions, 92 VA. L. REV. 707, 708 (2006).

${ }^{11}$ See infra, part II.A. The Supreme Court has explicitly adopted separate interpretations of Rule 3 for diversity cases and federal question cases. See Ragan v. Merchants Transfer \& Warehouse Co., 337 U.S. 530, 533 (1949) (in a diversity case, disregarding the potential applicability of Rule 3); Walker v. Armco Steel Corp., 446 U.S. 740 (1980) (adhering to Ragan); West v. Conrail, 481 U.S. 35, 39 (1987) (holding in a federal question case that Rule 3 determines commencement of an action for purposes of the statute of limitations). In Semtek and Shady Grove, the Court and the dissenters (respectively) adopted novel interpretations of Rules 41(b) and 23 (respectively) for diversity cases which have yet to affect how those Rules are applied in federal question cases. See infra, notes 127-28 and accompanying text.

${ }^{12}$ Rules of Decision Act, 28 U.S.C. $\S 1652$.

${ }^{13}$ Rules Enabling Act, 28 U.S.C. $\S 2072$. 
each of these approaches can be understood as marking different points along the same linear continuum. With pure substance at one end and pure procedure at the other, all legal rules can be thought of as lying at some point between these two poles. Part of what the Court has done wrong is to ignore this linear relationship by insisting, for example, in Semtek, that res judicata is "too substantive" to be addressed in the Federal Rules yet procedural enough to be governed by federal common law under the RDA. ${ }^{15}$

Normatively, this Article defends the dichotomy between substance and procedure. Given the linearity of substance and procedure, one could imagine the distinction either as a dichotomy of black and white, with every legal rule falling into one category or the other, or as a spectrum of gray, with many or even most legal rules falling in the mushy middle. Descriptively, of course, the latter view is more accurate. This Article claims, however, that the Court should, with full awareness of the grayness of all things, nevertheless classify each one as black or white, rather than attempt to accommodate both its procedural and its substantive aspects. The classification need not be the same for all purposes and in all contexts. The Court has good reasons for drawing the line between substance and procedure differently under the RDA, under the REA, and in other contexts. ${ }^{16}$ Within each context, however, a particular legal rule should be classified as either black or white: either substantive or procedural, governed by either federal or state law. This Article offers two reasons for preferring the black-white approach. First, the governing statutes contemplate a dichotomy between substance and procedure, and the Court is not authorized to use the ambiguity in that distinction to replace the statutory scheme with its own discretionary treatment of state law. In the face of an already delicate choice between state and federal law, trying to create

\footnotetext{
${ }^{14}$ See Amy Coney Barrett, Procedural Common Law, 94 VA. L. REV. 813 (2008) (describing and developing a theory for explaining the federal courts' inherent powers over procedure).

${ }_{15}^{15}$ See infra part II.B.1.

${ }^{16}$ But see Jay Tidmarsh, Procedure, Substance, and Erie (draft on file with the author) (arguing that the distinction between substance and procedure should not vary across contexts).
} 
nuanced accommodations between the two allows the perfect to become the enemy of the good. The Phase-Three approach may be feasible in the Supreme Court or in scholarly articles, but it does not produce good doctrine on the ground.

Second, eschewing Phase Three and returning to the blackwhite approach would promote democratic transparency in the states. Specifically, in addition to traditional Erie concerns about judicial lawmaking, Congress has set a policy of establishing a uniform body of trans-substantive procedural law. ${ }^{17}$ State lawmakers know this, and there is nothing wrong with federal courts expecting them to act accordingly. If they, as Representative Dingell famously offered, ${ }^{18}$ prefer to manipulate procedure in order to undermine the substantive rights they purport to have created, the threat of fixed procedures in diversity could and should restrain them. Too often, the Supreme Court treats legislative enactments as fixed, so that the game begins when the litigants start their forum shopping. The game begins earlier, in the legislature, and the Court's ad hoc, accommodating approach to state law in Erie's third phase creates the wrong incentives for that game.

Part I of this Article describes Erie's three phases and identifies a key characteristic of each phase's treatment of the relationship between state law and the Federal Rules. For those readers fortunate enough to have escaped law school before the Phase-Three approach emerged, part I.C describes Gasperini, Semtek, and Shady Grove in detail. It shows that while the First Phase was characterized by deference to state policy and the Second Phase by the ascendency of the Federal Rules, the nascent Third Phase is characterized by judicial discretion in formulating the law that controls in diversity

${ }^{17}$ See infra, text accompanying notes 229-32. Of course, Congress itself retains the prerogative to adopt special procedures in particular substantive contexts. This prerogative troubles some scholars, see infra part II.C.2, but its resolution is beyond the scope of this Article.

18 "I'll let you write the substance ... you let me write the procedure, and I'll screw you every time." Regulatory Reform Act: Hearing on H.R. 2327 Before the Subcomm. on Admin. Law and Governmental Regulations of the House Comm. on the Judiciary, 98th Cong. 312 (1983) (statement of Rep. John Dingell). 
cases. Part II.A argues that courts lack authority for exercising this discretion: the Phase-Three approach presents itself as creative problem-solving that crafts accommodations to serve state and federal interests; the proper role of the courts in this context is more limited. Part II.B argues that the Phase-Three approach also undermines separation of powers principles at the state level. The justices using this approach have justified it by the purported need to vindicate state policy choices. However, state-level democracy would be better served by forcing state lawmakers to enact their policy choices into substantive law, rather than allowing them to manipulate outcomes through procedure. ${ }^{19}$ One way to encourage them to do so is to adhere to a uniform system of federal procedure, rather than modifying procedure on an ad hoc basis as the Court did in Gasperini and Semtek. Thus, the justification for the Phase-Three approach in Gasperini and Semtek - the need to protect state lawmaking prerogatives-is misguided. Part III offers suggestions for minimizing the damage of those two cases: confining them to their facts and retaining to the conceptual structure of Phase Two.

\section{THE THREE PHASES OF ERIE}

Vertical choice of law doctrine has developed in three stages since Erie was decided. In Phase One, the Supreme Court held that most state laws it encountered were "substantive" for purposes of the RDA. ${ }^{20}$ In Phase Two, the Court reversed course, holding that most things were not only procedural but also already covered by federal law. ${ }^{21}$ The Federal Rules fared poorly in Phase One, while state law

\footnotetext{
${ }^{19}$ As noted above, "substance" and "procedure" are fluid categories and are inextricably intertwined. They are, nonetheless, "the terms the Enabling Act Uses," Ely, supra note 1 , at 724 , and the existence of dawn and dusk does not negate the difference between night and day. The question is what to do when the cases of dawn and dusk arise. This article proposes that we judge the Federal Rules according to the terms o the REA and call that realm of federal law "procedural" and thus applicable in diversity cases. Everything else is, in this context, "substantive," which leaves plenty of room for state lawmakers to carry out their policies. This Article is agnostic on whether the current approach to assessing the validity of the Rules under the REA is adequate.

${ }^{20}$ See infra, Part I.A.

${ }^{21}$ See infra, Part I.B.
} 
fared poorly in Phase Two. In both of these phases, however, the Court honored the need to choose: state law either did or did not apply.

The Phase-Three approach strikes out in a new direction. ${ }^{22}$ It began, in Gasperini, with the long-acknowledged observation that substance and procedure are inextricably intertwined. ${ }^{23}$ A law that on its face regulates procedure may be intended to serve a substantive policy. In Phases One and Two, this reality meant that the decision whether to apply state law was often difficult. In Phase Three, the justices using the new approach have taken the initiative to craft compromises that accommodate state policy while retaining federal control. The nascent Third Phase is thus characterized by the federal courts exercising discretionary authority over whether and how to accommodate what they perceive to be state policy preferences expressed in state procedural law.

\section{A. Phase One: Deference to the States}

The Supreme Court held in Erie Railroad v. Tompkins ${ }^{24}$ that the Rules of Decision Act requires a federal court sitting in diversity ${ }^{25}$ to apply the substantive law of the state in which it sits. ${ }^{26}$ In the standard telling of the story, the reasons for the decision were both jurisprudential and political. Jurisprudentially, legal realism and

${ }^{22}$ See infra, Part I.C.

${ }^{23}$ See, e.g., Gasperini v. Ctr. for Humanities, 518 U.S. 415, 426 (1996).

${ }^{24} 304$ U.S. 64.

${ }^{25}$ State substantive law may apply in federal court in contexts other than diversity jurisdiction, such as when a state law claim is litigated under the supplemental jurisdiction granted by 28 U.S.C. $\$ 1367$. For the sake of convenience, this Article follows the common practice of referring to Erie questions as arising primarily in diversity cases.

${ }^{26}$ Erie, 304 U.S. at 78. More precisely, federal courts must follow state law "rules of decision,"28 U.S.C. $\$ 1652$, a requirement that in retrospect has been understood as drawing a distinction that maps, at least approximately, onto the concepts of "substance" and "procedure." Before Erie, federal courts sitting in diversity routinely applied state statutes and state common-law rules that were understood to be "local," but under the doctrine of Swift v. Tyson, 41 U.S. 1 (1842), they followed their own lights on questions of general common law. 
positivism had swept aside belief in a single, universal common law that could be discovered by state and federal courts alike. ${ }^{27}$ Politically, the old guard in the federal courts was adhering to common law doctrines-especially doctrines that hindered tort plaintiffs - that in state courts were giving way to the demands of new social realities in the wake of the industrial revolution. ${ }^{28}$ The Erie doctrine restricted the power of the federal diversity courts over substantive law, confining them to the task of providing an alternative forum for enforcing legal rights that are created and defined by the states.

Justice Reed, concurring in Erie, was the first to anticipate what would become the central meaning of Erie to future generations: the distinction between substance and procedure. He observed, "The line

${ }^{27}$ See Edward A. Purcell, The Story of Erie: How Litigants, Lawyers, Judges, Politics, and Social Change Reshape Law, in CiviL Procedure Stories at 23-24 (Kevin M. Clermont ed., 2004) (describing the pre-Erie "declaratory" theory of law); HOWARD FINK \& MARK TUSHNET, FEDERAL JURISDICTION: POLICY AND PRACTICE 190 (2d ed. 1987).

${ }^{28}$ See Purcell, supra note 27, at 25 ("[Before Erie], the federal courts were becoming identified with the new national economy and the protection of corporate rights, and their 'general' law decisions spread from commercial issues into most common-law fields and seemed to grow ever more favorable to corporate interests."); JoEllen Lind, "Procedural Swift": Complex Litigation Reform, State Tort Law, and Democratic Values, 37 AKRON L. REV. 717, 732 (2004) (“According to some commentators, Swift [v. Tyson, 41 U.S. 1 (1941),] secured the federal courts as 'business courts' used by corporations to resist the claims of workers seeking redress for injuries."); Adam N. Steinman, What Is the Erie Doctrine? (And What Does It Mean for the Contemporary Politics of Judicial Federalism?), 84 Notre DAME L. Rev. 245, 248 (2008) (“Justice Brandeis' ruling in Erie restrained a pro-corporate federal judiciary by eliminating its power to create substantive rules of federal common law, which had operated to displace state rules that were often less favorable to corporate litigants."). Given this historical context, it was ironic and perhaps politically convenient for the Court that in Erie itself state law favored the corporate defendant. A similar reversal of typical interests occurred in Shady Grove and may partly explain the alignment of liberal and conservative justices in that case. See Adam N. Steinman, Our Class Action Federalism: Erie and the Rules Enabling Act After Shady Grove, _ NOTRE DAME L. REV. _, 44-45 (forthcoming 2011) (draft on file) (arguing that the justices in Shady Grove may have been looking ahead to more typical cases, where defendants prefer the application of federal class action law and plaintiffs prefer state law). 
between procedural and substantive law is hazy but no one doubts federal power over procedure." ${ }^{29}$ Consistent with this point, Erie's First Phase was devoted primarily to developing a menu of tests for distinguishing substance from procedure under the RDA. ${ }^{30}$ When a litigant proposes that a particular state law should govern in a diversity action, and no federal law or Rule supersedes the state law, federal courts ask whether the matter is outcome-determinative in a run of cases, ${ }^{31}$ a test which was later refined to focus on the "twin aims" of Erie: avoiding inequitable outcomes and discouraging forum shopping. ${ }^{32}$ If so, then state law should apply. ${ }^{33}$ Depending on the circumstances, courts may also balance state interests and Erie concerns against other federal interests that may favor the application of federal law. ${ }^{34}$

${ }^{29}$ Erie, 304 U.S. at 92 (Reed, J., concurring in part and concurring in the result) (citation omitted).

${ }^{30}$ The Court at times refused to describe the distinction as one between substance and procedure, perhaps wishing to retain those terms for marking the bounds of the REA. See Guaranty Trust v. York, 326 U.S. 99, 109 (1945) ("It is ... immaterial whether statutes of limitations are characterized either as 'substantive' or 'procedural' in State court opinions in any use of those terms unrelated to the specific issue before us."). This Article refers to both the REA and the RDA-and, for that matter, the powers of Congress and the courts to regulate judicial proceedings-as distinguishing between "substance" and "procedure," while recognizing that the dividing line is in a different place under each regime. I will usually refer to matters as being either substantive or procedural "for purposes of the REA [or the RDA, or inherent powers, or whatever]." For readers who prefer a more prominent reminder that these labels are conclusory rather than inherent in the matters discussed, I suggest globally replacing "substance" and "procedure" with more clearly arbitrary terms, such as "Salt" and "Pepper," or perhaps "matters governed by state law" and "matters governed by federal law."

${ }^{31}$ Scholars have offered several formulations for determining when a rule of law is outcome-determinative in a meaningful sense, rather than in the trivial sense that a litigant who refuses to follow technical rules about, say, paper size will surely lose. See, e.g., Tidmarsh, supra note 16 (proposing an ex ante valuation approach).

${ }^{32}$ Hanna v. Plumer, 380 U.S. 460, 466-67 (1965).

${ }^{33}$ Hanna, 380 U.S. at 470.

${ }^{34}$ Byrd v. Blue Ridge Rural Elec. Coop., 356 U.S. 525, 538 (1958). Byrd was the only major case in the RDA line that refused to follow state law in Phase One, concluding that federal practice, rather than state, determined the division of responsibility between judge and jury in federal court. Byrd involved the potential applicability of the Seventh Amendment, rather than a Federal Rule of Civil Procedure. Although the Court did not reach the question whether the Seventh 
Although Justice Reed's comment in Erie could be read as implicitly insisting that the brand-new Federal Rules of Civil Procedure not be disregarded in diversity cases, the pattern that emerged was one of avoiding or neglecting the Rules in cases that came to the Court as "Erie cases." For almost the next three decades, the Court often bent over backwards to apply state law, holding that state law governed even such plausibly procedural matters as statutes of limitations, enforcement of arbitration clauses, and bond requirements. ${ }^{35}$ For example, the Court showed great deference to the states in Ragan v. Merchants Transfer \& Warehouse Company. ${ }^{36}$ The question in Ragan was whether the plaintiff had satisfied the statute of limitations by filing the complaint in federal court. ${ }^{37}$ According to Federal Rule 3, an action is "commenced" as soon as it is filed, which would seem to indicate that any limitations period

Amendment required the outcome, the Court made plain that it reasoned in the shadow of the Seventh Amendment by introducing the concept of "countervailing federal interests" into the Erie analysis. Confronted with a potential constitutional command, the Court at last remembered that federal law is supreme; in this sense, Byrd can be seen as a forerunner of the Second Phase. See Byrd, 356 U.S. at 537539.

Scholars disagree about the continuing viability of Byrd. Some point out that the Supreme Court has rarely cited it and has not expressly followed its framework. See, e.g., Thomas D. Rowe, Not Bad for Government Work: Does Anyone Else Think the Supreme Court is Doing a Halfway Decent Job in Its Erie-Hanna Jurisprudence?, 73 NOTRE DAME L. REV. 963, 987 (1998) (criticizing scholars who treat Byrd as the dominant framework). Others argue that despite the lack of explicit citation, Byrd's conceptual structure has influenced the Court's analysis in many cases and that it remains the best framework for approaching Erie questions. See, e.g., Richard D. Freer and Thomas C. Arthur, The Irrepressible Influence of Byrd, 20 CREIGHTON L. REV. _ (forthcoming 2011) (draft on file); Kevin M. Clermont, The Repressible Myth of Shady Grove, _ NoTRE DAME L. REV. _, 13-14 (forthcoming 2011) (draft on file).

${ }^{35}$ See Guaranty Trust Co. v. York, 326 U.S. 99 (1945) (length of statute of limitations); Ragan v. Merchants Transfer \& Warehouse Co., 337 U.S. 530 (1949) (what action is needed to toll statute of limitations by initiating litigation); Cohen v. Beneficial Indus. Loan Corp., 337 U.S. 541 (1949) (bond requirement); Bernhardt v. Polygraphic Co. of Amer., 350 U.S. 198 (1956) (arbitration). ${ }^{36} 337$ U.S. 530 (1949). Relying heavily on stare decisis, the Court reaffirmed the outcome of Ragan in Walker v. Armco Steel Corp., 446 U.S. 740, 749, 750-51 (1980) (stating that Rule 3's definition of "commencement" was relevant to internal court processes rather than to the statute of limitations).

${ }^{37}$ Ragan, 337 U.S. at 531. 
stops running. ${ }^{38}$ State law, however, provided that an action was not "commenced" until the summons had been served. ${ }^{39}$ The Supreme Court acknowledged that federal courts treated Rule 3 as authoritative on this question. ${ }^{40}$ The court nonetheless insisted that local law must govern. ${ }^{41}$ In non-diversity cases, however, Rule 3 continued to be understood as defining commencement for limitations purposes. ${ }^{42}$ In diversity cases it meant something different. The characteristic feature of this First Phase was the Court's finding that almost all law was "substantive" and thus controlled by the states, even to the point of disregarding a Federal Rule of Civil Procedure. ${ }^{43}$

\section{B. Phase Two: The Imperial Rules}

By apt coincidence, Erie was decided in 1938, the same year the Supreme Court first promulgated uniform, trans-substantive Federal Rules of Civil Procedure for use in federal courts, pursuant to the

${ }^{38}$ Fed. R. Civ. Proc. 3.

${ }^{39}$ Ragan, 337 U.S. at 531 \& n.4 (describing state law).

${ }^{40}$ Ragan, 337 U.S. at 533 (citing Bomar v. Keyes, 62 F.2d 136, 141 (2d Cir. 1947)). This interpretation of Rule 3 was confirmed in West v. Conrail, 481 U.S. 35,39 (1987) ("[W]e now hold that when the underlying cause of action is based on federal law and the absence of an express federal statute of limitations makes it necessary to borrow a limitations period from another statute, the action is not barred if it has been 'commenced' in compliance with Rule 3 within the borrowed period.").

${ }^{41}$ Ragan, 337 U.S. at 533.

${ }^{42}$ See West v. Conrail, 481 U.S. 35, 39 (1987).

${ }^{43}$ See Scalise v. Beach Aircraft Corp., 47, F.R.D. 148, 150 (D. Del. 1969) ("Ragan seemed to assert the supremacy of local law over Federal Rules in diversity cases whenever local law would have barred the action had it been brought in a state court."). The dual-interpretation problem can be elided by treating the "federal" version of each Federal Rule as a judicial gloss akin to common lawmaking. If that gloss is "substantive" for RDA purposes, it must give way to a "state" version of the Federal Rule in diversity cases. See Steinman, What Is Erie, supra note 28, at 282-87. However, this is not how the Supreme Court has framed its analysis in the dual-interpretation cases. See Clermont, Repressible Myth, supra note 34, at 29 (stating that Shady Grove contradicted the predictions of this theory); comment by Adam Steinman on civil procedure professors' listserv, 4/3/10 (on file with author). 
Rules Enabling Act of $1934 .{ }^{44}$ Alongside the developing Erie doctrine distinguishing substance from procedure under the RDA, a separate line of cases addressed the validity of particular Federal Rules, under the mandate of the REA that the Rules govern "procedure" and do not "modify or abridge substantive rights." 45 The REA cases-most notably Sibbach v. Wilson \& Co. ${ }^{46}$-adopted a much broader understanding of the procedure category: to this day, anything that "really regulates procedure" is valid territory for the Federal Rules. ${ }^{47}$

During Phase One, the Supreme Court generally treated RDA/Erie cases separately from REA cases. In Sibbach, for example, a possible collision between the two statutes was avoided by the plaintiff's concession that the matter was "procedural." ${ }^{, 8} \mathrm{By}$ such avoidance, the Phase-One deference to state law in Erie cases was able to co-exist with Sibbach's deferential posture toward the Rules.

Sibbach and the REA collided with Erie and the RDA in Hanna v. Plumer,${ }^{49}$ which marks the beginning of Erie's Second Phase. Hanna recognized that if valid, controlling federal law dictated a result, that law superseded any state law, under the Supremacy Clause as well as under the language of the RDA. ${ }^{50}$ Unlike Ragan, Hanna implicitly recognized that the Federal Rules are federal laws like any other. They thus control whenever they validly apply. ${ }^{51}$

${ }^{44} 28$ U.S.C. § 2072; Pub. L. No. 73-415, ch. 651, § 1, 48 Stat. 1064 (1934).

${ }^{45} 28$ U.S.C. 2072.

${ }^{46} 312$ U.S. 1 (1941).

${ }^{47}$ See Shady Grove Orthopedic Assoc. v. Allstate Insur. Co., _ U.S. _, 130 S.Ct. 1431, 1444 (2010) (affirming that "really regulates procedure" remains the test under the REA). See also Clermont, Repressible Myth, supra note 34, at 24 (arguing that eight justices assented to this conclusion in Shady Grove).

${ }^{48}$ Sibbach, 312 U.S. at 10-11.

49380 U.S. 460 (1965).

${ }^{50}$ Hanna, 380 U.S. at 472 . The RDA explicitly exempts instances in which "the Constitution or treaties of the United States or Acts of Congress" apply and prevent the application of state law. 28 U.S.C. $§ 1652$.

${ }^{51}$ See Hanna, 380 U.S. at 473-74 ("To hold that a Federal Rule of Civil Procedure must cease to function whenever it alters the mode of enforcing state-created rights 
In Hanna, this issue played out on the question of service of process. State law required personal service on the defendant, while Federal Rule 4 offered options for substituted service. ${ }^{52}$ Under cases like Ragan, the defendant had a plausible argument that the mode of service constituted substantive state policy to which the federal court should defer. ${ }^{53}$ Rule 4 , however, was valid under the "really regulates procedure" standard from Sibbach ${ }^{54}$ It was therefore a valid federal law that spoke directly to the question, and it trumped state law. ${ }^{55}$

After Hanna, the Court once again swung to the extreme, this time aggressively reading federal law to displace state law. ${ }^{56}$ The zenith of this Phase is illustrated by a pair of Alabama cases. In one, the plaintiff argued that a federal court sitting in diversity should follow Alabama courts in refusing to enforce forum-selection clauses. ${ }^{57}$ Such clauses were disfavored in Alabama. ${ }^{58}$ Although no federal law requires that forum-selection clauses be enforced, the Supreme Court held that the general change-of-venue statute covered

would be to disembowel either the Constitution's grant of power over federal procedure or Congress' attempt to exercise that power in the Enabling Act."). ${ }^{52}$ Hanna, 380 U.S. at 463 (describing the differences between state and federal requirements). Commentators have pointed out that the perceived incompatibility between state and federal law could have been avoided. State law, like federal law, allowed substituted service to initiate the case but required personal service to toll the statute of limitations. Hanna thus appears inconsistent with Ragan not only as a matter of theoretical approach but also in producing an irreconcilable outcome. $C f$. supra, note 43 and accompanying text.

53 See Ragan v. Merchants Transfer \& Warehouse Co., 337 U.S. 530 (1949) (holding that state law determines when an action has "commenced," for purposes of tolling the statute of limitations). Because state law determines whether service is required to toll the statute of limitations, it makes sense that state law would determine how service must be performed.

${ }^{54}$ See Hanna, 380 U.S. at 464. Hanna did not discuss, but later Courts and commentators have suggested, that a Rule could be generally valid under Sibbach but invalid as-applied. See infra, text accompanying notes 110-24.

${ }^{55}$ Hanna, 380 U.S. at 464.

${ }^{56}$ The one exception is Walker v. Armco Steel Corp., 446 U.S. 740 (1980), discussed infra, note 67.

${ }^{57}$ Stewart Org. v. Ricoh, 487 U.S. 22, 24 (1988).

${ }^{58}$ Stewart, 487 U.S. at 24. 
the territory and therefore superseded Alabama law. ${ }^{59}$ The other Alabama case dealt with a state statute requiring defendants to pay penalties for unsuccessful appeals. ${ }^{60}$ Again, no federal law appeared directly on point. The Court, however, looked to provisions in the Federal Rules of Appellate Procedure that deal with taxation of costs on appeal. ${ }^{61}$ The Federal Rules gave judges discretion to tax costs on appeal. In the Phase-Two enthusiasm for Federal Rules over state law, these federal provisions were sufficient to cover the territory of penalizing unsuccessful appeals, and therefore to justify disregarding the state law. ${ }^{62}$ The Second Phase, then, was characterized by the Court's more aggressive use of federal procedural law to avoid obligations to advance state policies.

After Hanna, it was also clear that there were two separate standards for distinguishing substance from procedure. In what Hanna called "unguided Erie" analysis, ${ }^{63}$ courts distinguish between substance and procedure by using the twin aims of Erie in combination with earlier precedents such as Guaranty Trust and Byrd, which ask whether the rule is outcome-determinative, whether it is bound up with substantive rights, and whether there are countervailing federal interests. ${ }^{64}$ On the spectrum from substance to procedure, these tests mark a dividing line somewhere in the midst of an admittedly large gray area. In contrast, when the analysis is "guided" by the existence of a Federal Rule on point, the Court is much more strongly inclined to find that the matter is procedural.

\footnotetext{
${ }^{59}$ Stewart, 487 U.S. at 28.

${ }^{60}$ Burlington N. R. v. Woods, 480 U.S. 1, 3 (1987). The penalty was ten percent of the judgment, plus costs on appeal.

${ }^{61}$ Burlington, 480 U.S. at 4.

${ }^{62}$ Burlington, 480 U.S. at 7. A court anxious to defer to state law could have perceived a difference in purpose that would allow simultaneous application of the state and federal laws. Taxation of costs alleviates a small portion of the financial cost of litigation, while a ten percent surcharge on the judgment would usually be a more substantial amount and appeared to be directed at abuse of the appellate process as a delay tactic.

${ }^{63}$ Hanna v. Plumer, 380 U.S. 460, 471 (1965).

${ }^{64}$ See Guaranty Trust Co. v. York, 326 U.S. 99, 109 (1945) (outcomedetermination test); Byrd v. Blue Ridge Rural Elec. Coop., 356 U.S. 525, 535 (1958) (Byrd balancing test).
} 
That is, the Federal Rules of Civil Procedure get the benefit of the doubt that they really are procedural. Thus, the dividing line created by the REA is at a different point on the spectrum than the RDA line. A state law that would be deemed "substantive" under unguided Erie analysis might still be superseded by a Federal Rule of Civil Procedure.

For example, in Ragan, the Court concluded that the state's rule for how an action is "commenced" for statute of limitations purposes is substantive under Erie. ${ }^{65}$ This conclusion followed naturally from Guaranty Trust, which held that statutes of limitations were themselves substantive. ${ }^{66}$ The federal court in Ragan was therefore obliged to follow state practice and hold that a diversity action had not been commenced until the summons had been served. After Hanna, this case might have come out the other way. Rather than apply Erie's substance/procedure test, the Court could have applied the REA test to Rule 3, which says that an action is "commenced" when the complaint is filed. If the Rule was valid under the REA, it would control even in diversity cases and there would be no need for an unguided Erie analysis. ${ }^{67}$

${ }^{65}$ Ragan v. Merchants Transfer \& Warehouse Co., 337 U.S. 530, 533 (1949).

${ }^{66}$ Guaranty Trust Co. v. York, 326 U.S. 99, 110 (1945).

${ }^{67}$ Again, the discussion in the text sets aside the possibility that the Rule is invalid as-applied to displace a particular state law. See infra, text accompanying notes 110-24. Guaranty Trust, Ragan, and Hanna all deal with rules that affect a statute of limitations. While it makes some sense for them all to come out the same way, there has to be a dividing line somewhere in the gradual transition between substance and procedure. Moreover, any discrepancy between Guaranty Trust and reverse-Ragan is ameliorated by considering the purpose that "commencement" of the action serves. The state law in Ragan required service before the end of the limitations period, presumably so the defendant would receive notice within that period. This approach is compatible with the fact that many state courts will allow a complaint to languish for years without being served before it will be dismissed for failure to prosecute. In federal court, however, service is generally required within 120 days of filing, which would ameliorate the concerns that presumably motivated the state law in Ragan. See Fed. R. Civ. Proc. 4(m). Nonetheless, the Supreme Court reaffirmed Ragan after Hanna. See Walker v. Armco Steel Corp., 446 U.S. 740 (1980). Having already lived with the dual interpretation of Rule 3 for three decades, the court chose not to overrule Ragan. 
In the first two phases of Erie, the Court swung between two poles, first favoring state law, then federal law, especially the Federal Rules. What emerged, however, was a reasonably clear framework of federal supremacy tempered by the federalism of the RDA-or at least, it was reasonably clear after John Hart Ely explained it. ${ }^{68}$ In addition, the first two phases shared one overriding feature: in every case, the federal courts were told either to follow their normal federal practices, even in diversity cases, or to apply a particular rule of state law. In each case, the choice between these two options and the content of the rule to be applied flowed directly from federal laws, such as the REA, or from state laws, made binding on diversity courts by virtue of the RDA.

\section{Phase Three: A Third Way to Nowhere}

After swinging once to each extreme-over-zealous deference to state law, then aggressive implementation of the Federal Rulesone would hope that the Supreme Court would retreat to a happy medium. Instead, however, in Gasperini and Semtek, the Court unveiled a new approach to vertical choice-of-law in which, instead of choosing between state and federal practice, the Court made up its own rule that conformed to neither. ${ }^{69}$ Then in Shady Grove, the Court splintered: Four dissenters would have continued down the new path, while a four-justice plurality rejected it. ${ }^{70}$ The ninth, Justice Stevens, appeared to lean toward the dissenters' theoretical approach but disagreed with the application and so voted with the plurality. ${ }^{71}$

\footnotetext{
${ }^{68}$ See Ely, supra note 1 . Note that this conceptual framework would be consistent with a more rigorous approach to the REA's limitations on the Federal Rules.

${ }^{69}$ Gasperini v. Ctr. for Humanities, 518 U.S. 415 (1996) (discussed infra, part I.C.1); Semtek Int'l Inc. v. Lockheed Martin Corp., 531 U.S. 497 (2001) (discussed infra, part I.C.2).

${ }^{70}$ Shady Grove Orthopedic Assoc. v. Allstate Insur. Co., _ U.S. _, 130 S.Ct. 1431 (2010) (discussed infra, Part I.C.3).

${ }^{71}$ Shady Grove, 130 S.Ct. at 1448 (Stevens, J., concurring in part and concurring in the judgment).
} 
Robert Condlin has observed that Gasperini is "the type of precedent that, in retrospect, often turns out to be either the harbinger of a new doctrinal order, or an analytical wild card never heard from again." 72 Only time will tell "whether Gasperini becomes an integral part of a new Erie/Hanna overview, or is forgotten as a doctrinal frolic and detour." ${ }^{, 73}$ Two decisions later, the outcome is still unclear, especially because Justice Stevens, now retired, was the swing vote in Shady Grove. ${ }^{74}$ This Article aims to demonstrate that the Court should nip the Third Phase in its bud. Phase Three is characterized by creative interpretation that constitutes inappropriate freelancing by a Court that is supposed to be making a choice of law.

\section{Gasperini v. Center for the Humanities}

William Gasperini was a photographer who lent several hundred of his transparencies to the Center for the Humanities. ${ }^{75}$ The Center lost the negatives, and Gasperini sued for compensation. Sitting in diversity, the federal jury awarded $\$ 450,000$, and the trial judge denied the Center's motion to remit the verdict. ${ }^{76}$ On appeal, the Center argued that the Second Circuit should review the reasonableness of the verdict pursuant to a New York tort reform statute. ${ }^{77}$ The statute directed intermediate courts of appeal to determine whether a jury verdict "materially deviates from what would be reasonable compensation." 78 The Center argued that this statute reflected substantive policy in the State of New York. The Rules of Decision Act therefore required the federal courts to follow New York law in place of ordinary federal practice, in which appellate review of jury verdicts is limited by historic practices under

\footnotetext{
${ }^{72}$ Robert J. Condlin, "A Formstone of Our Federalism”: The Erie/Hanna Doctrine and Casebook Law Reform, 59 U. MiAMI L. REV. 475, 525 (2005).

${ }^{73}$ Condlin, supra note 66, at 525.

${ }^{74}$ Even the Shady Grove plurality, however, joined in the Phase-Three decision in Semtek. Indeed, Justice Scalia authored both Semtek and the Shady Grove plurality opinion.

${ }^{75}$ Gasperini v. Ctr. for Humanities, 518 U.S. 415, 419 (1996).

${ }^{76}$ Gasperini, 518 U.S. at 419-20.

${ }^{77}$ Gasperini, 518 U.S. at 421.

${ }^{78}$ Gasperini, 518 U.S. at 421 (quoting N.Y. Civ. Prac. L. \& Rules § 5501(c)).
} 
the common law. The Second Circuit agreed and ordered that the verdict be reduced. ${ }^{79}$

In the Supreme Court, Gasperini argued that the New York statute conflicted with the Seventh Amendment. ${ }^{80}$ The Supreme Court appeared to agree, ruling that federal appellate courts cannot apply the New York standard. ${ }^{81}$ Under prior doctrine, that would have been the end of the matter. Because there is valid federal law on point, it preempts the state statute; federal courts obviously cannot rely on the RDA as grounds for ignoring the Seventh Amendment. Indeed, in Byrd v. Blue Ridge Electric, the mere shadow of the Seventh Amendment was enough to push the Court to declare the division of labor between judge and jury to be a matter of procedure, governed by federal law even in diversity cases. ${ }^{82}$

In Gasperini, however, the Court, did not stop there. Although it adhered to its view that federal law controlled, it changed federal law by inventing a new procedure to accommodate what it saw as New York's substantive concerns. Although the Seventh Amendment barred the Court of Appeals from reviewing the reasonableness of the jury verdict, the Court held that the trial court could perform that review, under the standard set by the statute. ${ }^{83}$ The result was "a pastiche of federal and state law, but neither the one nor the other." 84

${ }^{79}$ Gasperini, 518 U.S. at 421.

${ }^{80}$ Gasperini, 518 U.S. at 426. The Gasperini dissent also argued that the New York law was displaced by Federal Rule 59. The majority responded to this argument in a footnote, indicating that the majority disagreed with Justice Scalia about the scope of the Rules. For purposes of this Article, issues involving the applicability of a Federal Rule are adequately presented by Semtek and Shady Grove, so I follow the Court in passing lightly over that issue in Gasperini. See Gasperini, 518 U.S. at 467-68 (Scalia, J., dissenting); id. at 438, n. 22 (majority response).

${ }^{81}$ Gasperini, 518 U.S. at 439.

${ }^{82}$ Byrd v. Blue Ridge Rural Elec. Coop., 356 U.S. 525, 539 (1958) (stating that the Court's decision was made "under the influence-if not the command-of the Seventh Amendment" and noting in a footnote that the Court was not deciding the Seventh Amendment question).

${ }^{83}$ Gasperini, 518 U.S. at 436. The preceding paragraphs describe the New York law at issue as it is described in the opening paragraph of Gasperini and as it has generally been treated in commentary on that case. A more precise description of 


\section{Semtek v. Lockheed}

Semtek also involved the Court's crafting a federal alternative rather than simply choosing state law or ordinary federal practice. Semtek is a confusing case, in part because of the knotty procedural problem at its center: the claim-preclusive effect of a dismissal for failure to meet the statute of limitations. ${ }^{85}$ When a state court issues such a dismissal, state law governs the preclusive consequences. ${ }^{86}$ In California, where Semtek started, statute of limitations dismissals are not preclusive, so the plaintiff remains free to re-file in a state with a more generous limitations period. ${ }^{87}$ The extra twist was that the dismissal in Semtek was by a federal court sitting in diversity. In federal court, statute of limitations dismissals are usually preclusive. $^{88}$

The Supreme Court first asked whether the usual federal practice was controlling. Lockheed argued that the case was governed by Rule 41(b), which states:

Involuntary Dismissal: Effect Thereof. ... Unless the court in its order for dismissal otherwise specifies, a dismissal under this subdivision and any dismissal not provided for in this rule, other than a dismissal for lack of jurisdiction, for improper venue, or for failure to join a party under Rule 19, operates as an adjudication upon the merits. ${ }^{89}$

New York law, and a discussion of the ramifications of that description, can be found infra, part III.C.

${ }^{84}$ Dudley \& Rutherglen, supra note 10 , at 707.

${ }^{85}$ Semtek Int'1 Inc. v. Lockheed Martin Corp., 531 U.S. 497, 509 (2001) (“This case presents the question whether the claim preclusive effect of a federal judgment dismissing a diversity action on statute-of-limitations grounds is determined by the law of the State in which the federal court sits.").

${ }^{86} 28$ U.S.C. $\$ 1738$ (" $[\mathrm{J}]$ udicial proceedings ... shall have the same full faith and credit in every court within the United States ... as they have by law or usage in courts of such State ... from which they are taken."); Marrese v. Amer. Acad. of Orthopaedic Surgeons, 470 U.S. 373 (1985).

${ }^{87}$ Semtek, 531 U.S. at 499.

${ }^{88}$ Semtek, 531 U.S. at 500.

${ }^{89}$ Fed. R. Civ. Pro. 41(b). 
Before Semtek, this Rule was widely understood to instruct that all dismissals other than those listed can be claim preclusive as a matter of federal law. ${ }^{90}$ In Semtek, however, the Court continued the unfortunate practice, begun in Ragan, of reading a Federal Rule to mean something different in diversity cases than in federal question cases. Rule 41(b), said the Court, does not speak to claim preclusion at all. Rather, it merely bars the plaintiff from re-filing the case in the same court. ${ }^{91}$ The Court's stated reason for this implausible reading of Rule 41(b) was the fear that the Rule as written was too substantive. That is, the Court suggested that the natural reading of the Rule might run afoul of the REA because it would modify or abridge the substantive right to bring the claim. ${ }^{92}$

Having disposed of Rule 41(b), the Court was left with an unguided Erie choice: should it deem this matter substantive and apply state law or procedural and governed by some federal law? The twin aims of Erie favored applying state law. ${ }^{93}$ Moreover, the Court had just suggested that the preclusion question was "too substantive" to be covered by the Federal Rules. Nonetheless, the Court insisted that federal law must control the preclusive effects of diversity judgments. The stated reason for this insistence was concern for the federal courts' ability to use dismissal of a case as a sanction. ${ }^{94}$ What if, posited the Court, a state did not recognize such a dismissal as preclusive? As discussed below, this concern was a red

\footnotetext{
${ }^{90}$ See Michael J. Edney, Preclusive Abstention: Issue Preclusion and Jurisdictional Dismissals After Ruhrgas, 68 U. CHI. L. REV. 193, 205 (2001) ("Rule 41(b) directly addresses the preclusive effect of a dismissal before a full trial on the merits ...."); Patrick Woolley, The Sources of Federal Preclusion Law After Semtek, 72 U. CIN. L. REV. 527, 577 (2003) ("It is not surprising that [Rule 41] was the only Federal Rule that was understood to expressly address preclusion prior to Semtek."); Stephen B. Burbank, Semtek, Forum Shopping, and Federal Common Law, 77 NoTRE DAME L. REV. 1027, 1045-46 (2002) (concluding based on the history of Rule 41's drafting that the Rule was intended to govern only eligibility for preclusion).

${ }^{91}$ Semtek, 531 U.S. at 505.

92 Semtek, 531 U.S. at 506; see Clermont, Repressible Myth, supra note 34, at 21 (calling the Semtek interpretation of Rule 41(b) "strangely narrow").

93 Semtek, 531 U.S. at 508.

${ }^{94}$ Semtek, 531 U.S. at 508.
} 
herring. ${ }^{95}$ For the Court, however, it was the justification for declaring that the Court itself had inherent power over a matter it had just deemed too substantive for a Federal Rule.

In a final twist, the Court reverted to Erie principles to decide what the federal common law rule should be. ${ }^{96}$ Rather than choose a uniform rule of federal law, the Court held that federal common law would borrow the rule of the forum state unless, on a case-by-case basis, there was an important federal reason to choose a different rule. $^{97}$

\section{Shady Grove v. Allstate}

The most recent installment of the Third Phase is Shady Grove v. Allstate ${ }^{98}$ At issue in Shady Grove was another, earlier New York tort reform statute. This one prohibits class actions to recover "penalties," such as statutory interest. ${ }^{99}$ The New York statute conflicts with the ordinary understanding of Rule 23, which sets the conditions under which class actions are appropriate in federal court. $^{100}$

${ }^{95}$ See infra, text accompanying notes $163-66$.

${ }^{96}$ Semtek, 531 U.S. at 508-09 ("[A]ny other rule would produce the sort of 'forumshopping ... and ... inequitable administration of the laws' that Erie seeks to avoid.") (quoting Hanna).

${ }^{97}$ Semtek, 531 U.S. at 508-09. This rule is reminiscent of Byrd, in which a matter otherwise governed by state law under the RDA can be governed by federal law if there is a countervailing federal interest. The difference is that Byrd acknowledged an obligation to follow state law in the absence of such a federal interest, while the Semtek Court followed state law as a matter of federal judicial discretion.

${ }^{98}$ Shady Grove Orthopedic Assoc. v. Allstate Insur. Co.,__ U.S. _, 130 S.Ct. 1431 (2010).

${ }^{99}$ Shady Grove, 130 S.Ct. at 1436 (discussing N.Y. Civ. Prac. L. § 901). The prohibition on penalty class actions was enacted as part of a general revision of New York class action law in response to the adoption of Rule 23. See Stephen B. Burbank \& Tobias Barrington Wolff, Redeeming the Missed Opportunities of Shady Grove, _ UNIV. OF PENN. L. REV. _, 22 (forthcoming 2011). It reflected concerns that penalty class actions lead to over-enforcement. Id. at 70 .

${ }^{100}$ Shady Grove, 130 S.Ct. at 1435; see Fed. R. Civ. Proc. 23. Since its adoption and despite academic objections, Rule 23 has routinely been applied to class 
Allstate, seeking to avoid a $\$ 5,000,000$ class action in federal court when the lead plaintiff would only be entitled to $\$ 500$, argued that Rule 23 should be read more finely. ${ }^{101}$ Justice Ginsberg, writing for the four dissenters, followed the path of Ragan, agreeing with Allstate that Rule 23 should be read to come into play only if the substantive law itself authorized class actions. ${ }^{102}$ Justice Ginsburg did not pretend that this reading of Rule 23 was natural. Rather, she argued that courts should consciously read the Rule to avoid conflict with the state's substantive policy goals: they should "interpret the Federal Rules in light of a State's regulatory policy." "103

The plurality, in an opinion by Justice Scalia, rejected this argument that an individual state's policy should influence the interpretation of federal law. ${ }^{104}$ Justice Scalia wrote that Rule 23 should be given its natural meaning as long as that meaning is valid under the REA. ${ }^{105}$ Adhering to Sibbach's standard as a full statement of the REA's limitations, he maintained that as long as a Rule "really regulates procedure" in a general sense, it trumps any conflicting state law, regardless of whether the state enacted the law for substantive policy purposes rather than procedural ones. ${ }^{106}$ Justice Stevens, the fifth vote for rejecting the application of state law in Shady Grove itself, wrote separately to hold out the possibility that a Federal Rule of Civil Procedure could be invalid as applied in a rare case. ${ }^{107}$ A Rule that, in general, "really regulates procedure" might create such a disruption in state substantive policy that it would be invalid for abridging, enlarging, or modifying a substantive right. ${ }^{108}$

certifications without a prior determination that the underlying substantive law authorizes class recovery.

${ }^{101}$ Shady Grove, 130 S.Ct. at 1437.

${ }^{102}$ Shady Grove, 130 S.Ct. at 1468 (Ginsburg, J., dissenting).

${ }^{103}$ Shady Grove, 130 S.Ct. at 1468-69 (Ginsburg, J., dissenting).

${ }^{104}$ Shady Grove, 130 S.Ct. at 1440-41.

${ }^{105}$ Shady Grove, 130 S.Ct. at 1442.

${ }^{106}$ Shady Grove, 130 S.Ct. at 1444-45.

${ }^{107}$ Shady Grove, 130 S.Ct. at 1451 (Stevens, J., concurring in part and concurring in the judgment).

${ }^{108}$ Shady Grove, 130 S.Ct. at 1453-54 (Stevens, J., concurring in part and concurring in the judgment). 
However, Justice Stevens concluded that Shady Grovewas not such a case, so he voted not to apply the state law. ${ }^{109}$

The split in Shady Grove highlights an important debate over how to determine the validity of Federal Rules. The current test is that a Rule is valid if it "really regulates procedure." 110 This generous standard comes from subpart (a) of the REA, which authorizes regulation of "practice and procedure and rules of evidence."111 Academics have long bemoaned the Supreme Court's neglect of subpart (b), which many interpret as an independent limit on the Rules. ${ }^{12}$ That is, even a Rule that "really regulates procedure" might be invalid if it also "abridge[s], enlarage[s], or modif[ies] any substantive right." "113 Shady Grove exposed a split between those who would apply subpart (b) on a case-by-case, "retail" basis and those who would determine the validity of Federal Rules strictly at the "wholesale" level. ${ }^{114}$

Justice Scalia's plurality in Shady Grove took the "wholesale" approach. Rule 23 was evaluated on its own terms and was found to be targeted at the regulation of procedure. ${ }^{115}$ While the plurality

\footnotetext{
${ }^{109}$ Shady Grove, 130 S.Ct. at 1448 (Stevens, J., concurring in part and concurring in the judgment).

${ }^{110}$ Shady Grove, 130 S.Ct. at 1445.

${ }^{111} 28$ U.S.C. $\$ 2072(a)$.

${ }^{112}$ See, e.g., Ely, supra note 1, at 719-20; Leslie M. Kelleher, Taking "Substantive Rights" (in the Rules Enabling Act) More Seriously, 74 Notre DAME L. REV. 47, 48 (1998) (collecting citations); see also Stephen B. Burbank, The Rules Enabling Act of 1934, 130 U. PA. L. REV. 1015, 1108 (1982) (arguing that $\S 2072$ (b) does not have independent effect distinct from the effect of $\S 2072$ (a) but that both reflect more substantial limitations on the courts than current doctrine acknowledges).

${ }^{113} 28$ U.S.C. $§ 2072(b)$.

${ }^{114}$ In addition to the Shady Grove opinions, compare Ely, supra note 1, at 733-34 (advocating case-by-case determination of whether a state's interest in its laws is substantive or procedural) with Dudley \& Rutherglen, supra note 10, at 727 ("The cautionary example of what has happened in the related field of conflicts of laws, where case-by-case balancing of interests has threatened to destabilize the entire field, should lead the Supreme Court to reinforce rather than retreat from a uniform interpretation of general rules of procedure.").

${ }^{115}$ Shady Grove, 130 S.Ct. at 1444.
} 
inquired in a general sense whether the Rule regulated substantive matters, it did so without reference to the particular state law at issue. ${ }^{116}$ As it happens, the plurality's assessment of Rule 23 was especially deferential, even simplistic. The opinion characterized class treatment as merely a matter of joinder, ${ }^{117}$ disregarding powerful arguments to the contrary. One need not, however, take such a deferential approach to the Rules in order to analyze the validity of a Rule "wholesale." One could adopt a more rigorous approach to the REA's limitations and still apply them wholesale. The key to the wholesale approach is that it hinges on the substantive or procedural nature of the Rule itself, without regard to the state law that the Rule displaces. ${ }^{118}$

The Shady Grove dissent, and to a lesser extent Justice Stevens, would determine the validity of the Federal Rule, as applied, with reference to the state law. ${ }^{119}$ If the state law is understood to serve substantive aims but uses a procedural mechanism to achieve them, the Federal Rule may have to give way. ${ }^{120}$ For example, John Hart Ely explained that whether a state prohibition on court-ordered medical exams applied in federal court would depend on the reason for the state ban. ${ }^{121}$ If the ban was part of a general scheme of limited discovery, it would be deemed procedural and thus trumped by the federal practice. ${ }^{122}$ If, however, the state enacted the ban as substantive protection for the right to personal privacy, federal courts would have to honor it in diversity cases. ${ }^{123}$ In Shady Grove, the dissent argued that the state's restriction on class actions served the substantive goal of limiting liability under penalty clauses and was

\footnotetext{
116 Shady Grove, 130 S.Ct. at 1444.

117 See Shady Grove, 130 S.Ct. at 1443.

118 See Shady Grove, 130 S.Ct. at 1444.

${ }^{119}$ Shady Grove, 130 S.Ct. at 1464 (Ginsburg, J., dissenting); id. at 1451 (Stevens, J., concurring in part and concurring in the judgment).

${ }^{120}$ Shady Grove, 130 S.Ct. at 1464 (Ginsburg, J., dissenting); id. at 1452 (Stevens, J., concurring in part and concurring in the judgment).

${ }^{121}$ Ely, supra note 1 at 733-34 (using the facts of Sibbach v. Wilson \& Co., 312 U.S. 1 (1941)).

${ }^{122}$ Ely, supra note 1 at 734.

${ }^{123}$ Ely, supra note 1 at 734 .
} 
thus inapplicable in the particular circumstances of the case, even if Rule 23 is generally valid as a regulation of procedure. ${ }^{124}$

The retail side of the wholesale/retail debate is the first step toward the discretionary approach that characterizes Phase Three. In Shady Grove, the dissent would have adopted an ad hoc interpretation of Rule 23 designed to accommodate a particular state law. This form of accommodation is a step away from Gasperini and Semtek, in which the Court created its own procedures that combined elements of state and federal law. The degree of judicial discretion is greater in the latter two cases, but the willingness to strain federal law is the same and is still in keeping with Phase Three.

\section{WHAT'S WRONG WITH THE THIRD WAY}

Gasperini and Semtek have been extensively analyzed and criticized, and the same fate surely awaits Shady Grove. The divide between the plurality and the dissent in Shady Grove presents a stark choice between continuing the Phase-Three approach begun in Gasperini and Semtek or returning to something like the conceptual structure of Phase Two. Part II.B, below, argues that the judicial discretion that characterizes Phase Three is unwarranted. Part II.C refutes the primary theoretical justification for that discretion: While the Court has adopted a pose of vindicating federalism by accommodating state policies, the Phase-Three approach is neither required nor even necessarily helpful for protecting the results of democratic processes in the states.

\section{A. The Chorus of Criticism}

The nascent Third Phase represented by Gasperini and Semtek (and embraced by the Shady Grove dissent) has been criticized from several quarters for being confusing and for failing to give adequate guidance to the lower courts. ${ }^{125}$ Kevin Clermont offers mild praise for the Shady

\footnotetext{
${ }^{124}$ Shady Grove, 130 S.Ct. at 1468 (Ginsburg, J., dissenting).

${ }^{125}$ See Rowe, supra note 34, at 963-66 (summarizing criticism of Gasperini and defending the decision); Dudley \& Rutherglen, supra note 10, at 708 (describing a "chorus of academic criticism" for Gasperini and Semtek); see also Geoffrey C.
} 
Grove plurality for bringing greater clarity to Erie doctrine while backing off from what I am calling the Phase-Three approach. ${ }^{126}$ The most common specific complaint about Semtek and the Shady Grove dissent is their return to the practice of creating dual readings for Federal Rules: Semtek and the Shady Grove dissent both accepted strained, implausible interpretations of Federal Rules to be used only in diversity cases, with the more natural interpretation continuing to prevail in federal question cases. ${ }^{127}$ The creative textualism of Semtek's Rule 41 and the Shady Grove dissent's Rule 23 is perhaps to be admired as a matter of lawyerly semantic skill, but it should not be embraced by courts. ${ }^{128}$

Commentators have also noted that the ad hoc approach of the Third Phase is in tension with Erie itself. Earl Dudley and George Rutherglen observe that "federal district courts today arguably possess greater freedom to reach desired results in diversity cases than they had under Swift v. Tyson." 129 Douglas Floyd similarly complains that Gasperini's open-ended interest balancing will lead to "unwarranted subordination of substantive state objectives to ad hoc judicial perceptions of amorphous federal procedural 'interests.',"130

Hazard, Has the Erie Doctrine Been Repealed by Congress?, 156 U. PA. L. REV. 1629, 1635 (2008) (calling Gasperini “pitiful”).

${ }^{126}$ Clermont, Repressible Myth, supra note 34.

${ }^{127}$ See, e.g., Dudley \& Rutherglen, supra note 10, at 708-09 (summarizing the authors' criticisms of Gasperini and Semtek); J. Benjamin King, Clarification and Disruption: The Effect of Gasperini v. Center for Humanities, Inc. on the Erie Doctrine, 83 CORNELL L. REV. 161, 164 (1997) (arguing that Gasperini undermines reliance on apparently applicable Federal Rules).

${ }^{128}$ One reason for rejecting such unnatural readings in order to reach a result in a particular case is that potential for unforeseen consequences in other cases is substantial. For example, the Shady Grove dissent would separate the "substantive" question of whether class remedies are available on a particular cause of action from the "procedural" questions addressed by Rule 23. While perhaps a clever resolution of the case before it, such a holding would have opened the door to litigation over whether class remedies are "available" as to every cause of action, effectively creating a whole new field of law. See comment by Edward A. Hartnett on civil procedure professors' listserv, 3/31/10 (on file with author).

${ }^{129}$ Dudley-Rutherglen, supra note 10 , at 744-45. Interestingly, the lower courts do not seem as interested in exercising this freedom as does the Supreme Court. See infra, Part III.A.

${ }^{130}$ C. Douglas Floyd, Erie Awry: A Comment on Gasperini v. Center for Humanities, Inc., 1997 B.Y.U. L. Rev. 267, 269-70. 
Other commentators have praised both Gasperini and Semtek. Stephen Burbank claims responsibility for most of Semtek, although he parts ways with the Court over its strained reading of Rule 41(b), suggesting that the Rule should simply have been held invalid. ${ }^{131}$ Praise for Gasperini has come from those, like Thomas Rowe and Richard Freer, who applaud the effort to accommodate state law and to give independent, retail-level meaning to part (b) of the REA. ${ }^{132}$ Professor Freer, however, is critical of the Court's application Erie's twin aims, ${ }^{133}$ and Professor Rowe's praise was in part contingent on the Court's continued production of solid majority opinions, a record that was broken by the splintered decision in Shady Grove. ${ }^{134}$

This Article joins with the critics of the discretion exercised by the Supreme Court in Gasperini and the dissent in Shady Grove. It adds, in part II.B.1, that Semtek is of the same mold and, in part II.C, that democracy in the states may actually be better served by abandoning the Phase Three approach.

\section{B. The Supreme Court Should Not Freelance on Choice-of-Law Questions}

This section argues that the Supreme Court's freelancing on choiceof-law questions involves an unwarranted exercise of federal judicial discretion. In Semtek, the Court announced that federal common law would govern the preclusive effect of federal diversity judgments, declining to apply either Rule 41 or state law. Under the terms of Semtek itself, the Court's authority for creating common law was suspect, and the Court did not justify its claim of power. In Gasperini, the Court presented itself as creatively seeking an accommodation of its own devising between

\footnotetext{
${ }^{131}$ Burbank, Semtek and Forum Shopping, supra note 90, at 1039-47.

${ }^{132}$ Richard D. Freer, Some Thoughts on the State of Erie After Gasperini, 76 TEX. L. REV. 1637 (1998); Rowe, supra note 125. Professor Rowe supports allowing states to override Federal Rules of Civil Procedure, on substantive policy grounds, arguing that such overrides will be rare and could always be trumped by Congress. ${ }^{133}$ Freer, supra note 132, at 1654-57.

${ }^{134}$ Rowe, supra note 125, at 1014-15. Shady Grove also dashed Professor Rowe's hope that the Gasperini dissenters were driven primarily by Seventh Amendment concerns and would join the rest of the Court's deferential interpretive approach in future cases.
} 
state and federal law, effectively creating a federal common law of New York remedies. This, too, the Court failed to justify. In both cases, the Court should have eschewed the freelancing that characterizes the Third Phase.

\section{The Trouble With Semtek: The Court's Inherent Powers Cannot Logically Exceed the Power of the Court and Congress Acting Together.}

Semtek's reasoning is like a mobius strip. The question presented starts out as a seemingly procedural one regarding the effect of Federal Rule 41(b). ${ }^{135}$ But no, says the Court, the question is substantive and therefore not reachable by the Federal Rules. ${ }^{136}$ Turn the page again, however, and it is once again procedural—at least, procedural enough to be subject to the inherent powers of the federal courts. ${ }^{137}$ If preclusion is "too substantive" to be regulated by the Supreme Court and Congress acting together through the REA, then the courts should not be able to regulate it pursuant to their inherent power to regulate procedure.

The usual rule is that the preclusive effect of a judgment is governed by the law of the court that rendered the judgment. ${ }^{138}$ This rule allows the parties to make reasonable predictions of potential

\footnotetext{
${ }^{135}$ Semtek Int'l Inc. v. Lockheed Martin Corp., 531 U.S. 497, 501 (2001).

${ }^{136}$ Semtek, 531 U.S. at 503-04.

${ }^{137}$ Semtek, 531 U.S. at 508. This is not to suggest that questions of preclusion must be deemed inherently "substantive" or "procedural" for all purposes. The distinction may be made differently under the RDA and the REA. However, as discussed infra, this section, the inquiries under the two statutes are similar enough that a matter deemed "substantive" for REA purposes (under the current, generous standard, which is highly deferential to the Federal Rules) should also be deemed "substantive" for RDA purposes (under the unguided Erie analysis, which favors the "substantive" label and thus the application of state law). The difference between the REA and the RDA tests lies in the realm that is considered procedural in the sense that it may be governed by a federal Rule but, in the absence of a Rule, would be governed by state law rather than federal practice.

${ }^{138}$ See Howard M. Erichson, Interjurisdictional Preclusion, 96 MICH. L. REV. 945, 1002 (1998). Courts sometimes apply the preclusion law of the law-supplying jurisdiction from the first case. $I d$. Either way, preclusive effects are predictable, since they do not depend on the law of the enforcing jurisdiction.
} 
preclusive effects and to behave accordingly; it also vindicates the procedural interests of the forum, which uses future preclusive effects as tools for controlling the parties' behavior over the course of the litigation. ${ }^{139}$ Because the source of the law that will govern future preclusive effects should be ascertainable at the time the first judgment is rendered, we can imagine that every judgment contains an invisible footnote specifying the preclusion law that applies. A California judgment, for example, contains an invisible footnote summarizing California preclusion law. When that judgment is presented as a defense to litigation in a Maryland court, the Maryland court applies the decisions embodied in the judgment and the California rules of preclusion to the allegations made in the Maryland action. From these elements, it determines whether the Maryland action is precluded. The question in Semtek was: When a federal court in California sits in diversity, does the invisible footnote to its judgment contain California preclusion law or federal preclusion law?

As described above, the defendant in Semtek first argued that federal law controlled because Rule 41(b) made the federal judgment preclusive. ${ }^{140}$ According to the first part of the opinion, however, the Court adopted an implausible reading of Rule 41(b) because preclusion was dangerously substantive, even for REA purposes. ${ }^{141}$ The Court warned that reading Rule 41(b) to govern preclusive effect "would arguably violate the jurisdictional limitation of the Rules Enabling Act: that the Rules 'shall not abridge, enlarge or modify any substantive right.",142 This argument suggests that on the spectrum from substance to procedure, the preclusion question in Semtek falls on the "substance" side of the dividing line created by the REA. Semtek's justification for its narrow reading of Rule 41(b) was that that preclusion is "too substantive" for the REA. ${ }^{143}$

\footnotetext{
${ }^{139}$ See Erichson, supra note 138, at 1002-03.

140 Semtek, 531 U.S. at 501.

${ }^{141}$ Semtek, 531 U.S. at 503-04.

${ }^{142}$ Semtek, 531 U.S. at 1026 (quoting 28 U.S.C. \$2072(b)).

${ }^{143}$ One could read Semtek as addressing not preclusion generally but preclusive effect in the context of statute of limitations dismissals. This reading is discussed infra, text accompanying note part III.B, as an option for limiting Semtek's effect,
} 
As discussed in Part I, the dividing line created by the REA is different from the dividing line created by unguided Erie analysis pursuant to the RDA. The REA line favors the application of federal law, and thus favors the label "procedure." The RDA line does the opposite. The difference between the two is that some matters may be "procedural" for REA purposes but "substantive" for RDA purposes. Therefore, even the possibility of being "too substantive" for the REA should mean that preclusion is "substantive" for Erie purposes as well. ${ }^{144}$ That means that, under the RDA, the federal courts should follow state law. The invisible footnote of a diversity judgment would contain state law, and the preclusive effect of the judgment of a federal court sitting in diversity would be governed by the preclusion law of the state that provided the substantive law.

And indeed, the Court initially suggested that this outcome would be required, for it stated that applying the federal Rule would "in many cases violate the federalism principles of Erie ...." Citing Hanna, Guaranty Trust, and Walker v. Armco Steel, ${ }^{146}$ the Court argued that giving force to the federal rule would result in substantial variation in outcomes between state and federal court, leading to the inequities and forum shopping that the "twin aims" test is meant to prevent. ${ }^{147}$ So far, preclusion sounds substantive for Erie purposes, and substantive enough for REA purposes that a Rule treading the ground of preclusion should be drained of life. This analysis ought to mean that the federal courts are required by the RDA to follow state law.

In the second half of Semtek, however, the Court reversed course, deciding that the preclusive effect of diversity judgments

but it is not the most natural reading of the opinion, which speaks as if to questions of preclusion generally.

${ }^{144}$ In other words, the set of legal rules that are "procedural" for RDA purposes is a wholly contained subset of the set of legal rules that are "procedural" for REA purposes.

145 Semtek, 531 U.S. at 504.

146446 U.S. 740 (1980).

147 Semtek, 531 U.S. at 504. 
would instead be governed by federal common law. ${ }^{148}$ As support, the Court cited cases suggesting that federal law controlled the preclusive effect of federal judgments, but it conflated federal question cases with diversity cases and conflated the obligation to give full faith and credit to federal judgments with the determination of what such faith required. ${ }^{149}$ The Court also relied on a pre-REA case that it had already said no longer controlled. ${ }^{150}$ The justification for making federal common law takes up barely more than a page in the United States Reports, and nowhere does it identify the source of the Court's authority. ${ }^{151}$

Commentators have suggested that Semtek was based on the Supreme Court's inherent authority to govern procedural matters in the federal courts. ${ }^{152}$ Although the Court is generally obliged to follow congressional commands even in the realm of procedure, it is usually thought to be free to develop rules of practice and procedure, in the absence of congressional action or a governing Rule. ${ }^{153}$ Its authority to do so comes either from Article III's establishment of the judicial branch or from Congress's creation of lower courts and conferral of jurisdiction to decide cases. ${ }^{154}$ The problem with relying

\footnotetext{
${ }^{148}$ Semtek, 531 U.S. at 507-08.

149 Semtek, 531 U.S. at 507 (citing cases).

${ }^{150}$ Semtek, 531 U.S. at 507-08 (discussing Dupasseur v. Rochereau, 88 U.S. (21 Wall.) 130 (1874)).

${ }^{151}$ Semtek, 531 U.S. at 507-09.

${ }^{152}$ See Woolley, supra note 90, at 537 ("While the court did not identify the source of authority for a federal common law of preclusion, it would appear that statutes creating the federal courts and bestowing jurisdiction upon them provide an adequate basis - albeit and implicit one-for the development of common law rules in this area.").

${ }^{153}$ Joseph J. Anclien, Broader Is Better: The Inherent Powers of Federal Courts, 64 N.Y.U. ANN. SURV. AM. L., 37, 41 (2008) (describing the predominant view that inherent powers exist only in "cases of indispensable necessity" and arguing for a broader view); Robert J. Pushaw, The Inherent Powers of Federal Courts and the Structural Constitution, 86 IowA L. REV. 735, 743 (2001) (“As the early Justices recognized but the modern Court has forgotten, the Necessary and Proper Clause authorizes Congress alone to determine whether or not to bestow beneficial powers.").

${ }^{154}$ Barrett, supra note 14 (discussing the implications of these two lines of authority).
} 
on this inherent power to explain Semtek is that before turning to the inherent power, the Semtek Court had strongly suggested that the matter at issue was substantive under both the REA and the RDA. ${ }^{155}$ Of course, the location of the substance-procedure line may vary according to the legal context, and we have already said that it is different for the REA than for the RDA. The line could certainly lie in yet another location for purposes of inherent power. However, if preclusion is substantive for REA and RDA purposes, but procedural for inherent power purposes, then the realm of inherent power is larger than the realm that can be governed by Rules promulgated under the REA. This scheme seems unlikely. The Supreme Court has already interpreted the REA to permit any rule that "really regulates procedure." 156 This generous standard reflects the reality that Congress's blessing in the REA enhances the Court's inherent power. Just as in the Steel Seizure Cases, ${ }^{157}$ the powers belonging to one branch of government are at their strongest when that branch acts in concert with another branch. ${ }^{158}$ The Court's inherent power to make procedural law should not exceed its power to do the same when buttressed by congressional authority. ${ }^{159}$ As Elizabeth Lear has explained,

${ }^{155}$ Semtek, 531 U.S. at 503-04.

${ }^{156}$ Shady Grove Orthopedic Assoc. v. Allstate Insur. Co., _ U.S. _, 130 S.Ct. 1431, 1444 (2010) (adhering to this standard).

${ }^{157}$ Youngstown Sheet \& Tube Co. v. Swayer, 343 U.S. 579, 634 (1952) (Jackson, J., concurring) ("When the President acts pursuant to an express or implied authorization of Congress, his authority is at its maximum, for it includes all that he possesses in his own right plus all that Congress can delegate.").

${ }^{158}$ Cf. Craig Green, Repressing Erie's Myth, 96 CAL. L. REV. 595, 598-99 (2008) ("Federal common law could be analogized to Justice Jackson's discussion of presidential authority in Youngstown Sheet \& Tube Co. v. Sawyer. Jackson's opinion explains the basic interaction between Congress and a branch with largely derivative constitutional authority. I suggest that those dynamics work similarly whether one considers Congress and the President (Youngstown), or Congress and the Judiciary (federal common law).").

${ }^{159} C f$. Elizabeth T. Lear, Congress, the Federal Courts, and Forum Non Conveniens: Friction on the Frontier of the Inherent Power, 91 Iowa L. Rev. 1147, 1184 (2006) ("'[I]t would be very odd indeed if the Court could evade this restriction simply by relying on its inherent power.... The Rules of Decision Act represents the congressional vision of the appropriate balance between state law and inherent power lawmaking by the federal courts."). 
The Rules Enabling Act and the Rules of Decision Act are ... relevant to the scope of the Court's inherent power, representing efforts by Congress to minimize friction between the federal courts and Congress, and the federal courts and the States, respectively. Together they form the outer limits of judicial innovation on the procedural front. ... While Congress may enact substantive or procedural statutes that displace the substantive law of the States, the Rules of Decision Act prohibits the Court from doing so under the guise of the inherent power. ${ }^{160}$

For these reasons, the realm of inherent power should be a subset of the realm of the REA. If preclusion is substantive for RDA purposes, either the Federal Rule validly applies and controls, or else state law controls. Depending on whether the Semtek Court was correct in the first half of its opinion (calling preclusion substantive, for both REA and RDA purposes) or the second half (treating it as procedural), either the Court wrongly displaced the states' substantive authority or it wrongly ignored, through convoluted interpretation, its own prior promulgation of Rule 41(b).

There are two defenses that one could make of the Court's analysis in Semtek, but each ultimately fails. First, perhaps my conception of the spectrum from substance to procedure is misleadingly linear. I have suggested that matters of "procedure" under the RDA and inherent powers must be wholly contained subsets of matters that are "procedural" under the REA. Perhaps, however, the relationships among the RDA, the REA, and inherent

\footnotetext{
${ }^{160}$ Lear, supra note 159, at 1180-81; see also Wendy Collins Perdue, The Sources and Scope of Federal Procedural Common Law: Some Reflections on Erie and Gasperini, 46 U. KAN. L. REV. 751, 760 (1998) (“The Rules Enabling Act may constrain courts, even where they are not directly interpreting a Federal Rule of Civil Procedure but are instead creating a federal common law rule of 'practice and procedure.' As Professors Westen and Lehman argue, 'the statutory prohibition on rules that abridge "substantive rights" must be deemed to apply to judge-made rules too; otherwise, judges could do through common law adjudication what they cannot do through the carefully circumscribed and safeguarded mechanisms used to create the federal rule of civil procedure."”).
} 
power are multidimensional. There might then be a way to justify the Court's use of inherent power along a different axis. Second, perhaps preclusion truly is substantive: Semtek is justified not by the Court's inherent power over procedure but by substantive power to make federal common law.

The first defense would draw on the long-neglected part (b) of $\S 2072$, which prohibits a Federal Rule from abridging, enlarging, or modifying a substantive right. ${ }^{161}$ Commentators have long complained that the Court's "really regulates procedure" test for validity under the REA implements only $\S 2072$ (a), authorizing the Court to promulgate rules of practice and procedure. ${ }^{162}$ Many believe that some further constraint is needed in order to fulfill $\S 2072$ (b)'s command not to alter substantive rights. ${ }^{163}$ Preclusion is a classic example of a body of law that is "procedural" in a sense but can also reasonably be understood to alter substantive rights. ${ }^{164}$ It might then validly lie within the Court's inherent power over procedure while still being "too substantive" for the REA.

The problem with this first defense of Semtek is the RDA. Surely, if preclusion law alters substantive rights, it is substantive not just under the REA but also under Erie/Hanna/RDA. The RDA thus directs the federal courts to apply state law. The Semtek decision does not demonstrate that state law does not "apply," and thus control, under the terms of the RDA. Analogy to Justice Jackson's Steel Seizure framework is again useful here ${ }^{165}$ : While the Court's power over procedure is at its maximum when it acts in conjunction with Congress, as under the REA, the Court's power is minimal

\footnotetext{
16128 U.S.C. $\$ 2072$ (b).

${ }^{162}$ See, e.g., Ely, supra note 1, at 719-20; Kelleher, supra note 112, at 48 (collecting citations);

${ }^{163}$ Or that the two together should have more teeth than the "really regulates procedure" test has exhibited. See Burbank, The REA, supra note 112, at 1108 (arguing that $\S 2072$ (b) does not have independent effect distinct from the effect of $\S 2072$ (a) but that the Court's approach since Sibbach is too lenient).

${ }^{164}$ See Barrett, supra note 14, at 830-31 (treating preclusion as a matter of procedural common law but noting that its "status as 'procedural' is ... open to doubt").

${ }^{165}$ See supra, note 149 (discussing Steel Seizure).
} 
when it acts contrary to congressional command. ${ }^{166}$ The adoption of federal common law contrary to Congress's policy of following state law can be justified under the inherent power only to protect the core ability of the federal courts to perform their judicial function. ${ }^{167}$ That is a heavy burden, which the Semtek Court did not attempt to meet.

Similarly, any legal rule that would be deemed "procedural" for Erie/RDA purposes is also sufficiently procedural to be within the scope of the REA. ${ }^{168}$ A matter cannot be "too substantive" for the REA yet within the scope of inherent power. The first defense therefore fails.

The second defense is that preclusion is, indeed, substantive for most or all purposes, and that the authority claimed in Semtek was not the inherent power over procedure but common law-making power such as the Court exercises over maritime law or suits to which the United States is a party. ${ }^{169}$ In order to make federal common law, however, the Court is supposed to identify the federal

\footnotetext{
${ }^{166}$ See Youngstown Sheet \& Tube Co. v. Sawyer, 343 U.S. 579, 637-38 (1952) (Jackson, J., concurring) ("When the President takes measures incompatible with the expressed or implied will of Congress, his power is at its lowest ebb, for then he can rely only upon his own constitutional powers minus any constitutional powers of Congress over the matter.").

${ }^{167}$ See supra, part II.B.1 (discussing the scope of inherent power relative to power under the REA).

${ }^{168}$ This discussion assumes that a Federal Rule is either valid or invalid under the REA, ignoring the possibility that a Rule might be generally valid but invalid as applied to displace a particular state practice that serves substantive goals. See infra part II.C. (discussing reasons why Rules should not be invalidated as applied). The issue of as-applied invalidity was not at play in Semtek since the case involved the general rules of what preclusion laws should apply, not a state's idiosyncratic use of matters ordinarily deemed procedural to achieve a substantive policy goal.

${ }^{169}$ See Barrett, supra note 14, at 831-32 ("In Semtek, the Supreme Court hinted that its power to formulate federal rules of preclusion rests on the same ground as its power to formulate substantive common law: the lack of congressional guidance in an area of clearly federal concern."). However, Barrett also points out that the Court did not elaborate on this justification in Semtek and that its other preclusion cases have been silent on the source of power. Id. at 832 .
} 
interest that is at stake. ${ }^{170}$ There are two federal interests that are potentially at stake in the preclusive effect of a diversity judgment: First, there is an interest in ensuring that federal judgments receive full faith and credit. It is not apparent, however, that this interest extends any further than ensuring that the diversity judgment receives the same respect that would be accorded to a state court judgment. Second, there is a federal interest in the conduct of the initial litigation, which will be affected by the anticipated preclusive effects of the judgment. ${ }^{171}$ That, however, is a procedural interest, and to justify federal common law on that basis without invoking the federal courts' power to regulate their own proceedings would be too fine a cut.

The Semtek Court did describe one situation in which such a federal procedural interest would exist and would require a federal rule to control preclusive effect. ${ }^{172}$ That one situation was the possibility that a state's courts might not give preclusive effect to dismissal as a sanction. ${ }^{173}$ This policy would conflict with a federal court's interest in making its sanction stick. The Semtek Court seemed to fear that, having intimated that preclusion was substantive under the REA and flat-out stated that it was substantive under Erie, it would be forced to live with the whims of states that impose only ineffective sanctions on misbehaving litigants. This example is an unconvincing basis for replacing state preclusion law with federal common law if preclusion is, indeed, properly understood as substantive for REA and RDA purposes. State courts, like federal courts, prefer their sanctions to be meaningful, so it seems unlikely that a state would adopt such a self-defeating policy as the Semtek Court imagined. Moreover, there is no need to contort either preclusion law or Erie doctrine to deal with that slight possibility. A federal court certainly has the power to deprive a misbehaving party of property as a sanction, whether that property takes the form of

\footnotetext{
${ }^{170}$ See Barrett, supra note 14 , at 832 (identifying the grounds for judicial power to formulate substantive common law).

${ }^{171}$ Erichson, supra note 138, at 1002-03 (discussing the forum's interest in the the preclusion rules that would later be applied to a judgment).

${ }^{172}$ Semtek Int'l Inc. v. Lockheed Martin Corp., 531 U.S. 497, 509 (2001).

${ }^{173}$ Semtek, 531 U.S. at 509.
} 
cash or a cause of action. ${ }^{174}$ That hardly means that that we need a federal common law of property. Moreover, Byrd already permits case-by-case balancing of state and federal interests, so that a matter that would otherwise be controlled by state law can be federalized because of compelling federal concerns in a particular situation. ${ }^{175}$ If the Supreme Court truly believes that preclusion is an otherwise substantive matter, the dismissal-as-sanction example at best warrants federal common law only as an exception, not as the general rule.

The outcome reached in Semtek has intuitive appeal: preclusion has a substantive feel, especially in the context of a statute-oflimitations dismissal, yet an equally strong intuition says that federal courts must retain control over the enforcement of their judgments. As discussed below, these concerns could be addressed without the free-wheeling approach to judicial authority on display in Semtek. ${ }^{176}$ The Supreme Court should not shake off the yoke of the REA by hinting that a matter is substantive while simultaneously claiming inherent procedural authority to regulate the matter on its own.

\section{The Trouble With Gasperini: The RDA Does Not Authorize a Body of Federal Common Law.}

Other than the Supreme Court's inherent power over procedure, there is only one possible source of authority for making a federal common law of preclusion for diversity cases. It is also the only available source of authority for making a federal common law of New York tort damages in Gasperini. That source is the RDA itself. The point of Erie, however, was that neither the RDA nor any other

\footnotetext{
${ }^{174}$ See Chambers v. Nasco, Inc., 501 U.S. 32, 52 (1991) (holding that Erie did not prevent a federal court from using its inherent power to sanction a litigant, even where the state court might not have imposed a similar sanction).

${ }^{175}$ See Byrd v. Blue Ridge Rural Elec. Coop., 356 U.S. 525 (1958) (allowing courts to balance Erie concerns against countervailing federal interests); $c f$. Woolley, supra note 90 (arguing that even under Semtek, most preclusion questions will be governed by federal law because the federal interest will predominate).

${ }^{176}$ See infra, part II.C.
} 
provision of federal law authorizes federal courts to create general common law. ${ }^{177}$ To the extent that the Gasperini Court perceived itself as creatively accommodating state law to the requirements of federal constitutional procedure, it reached beyond its authority, as it did in Semtek.

Congress's grant of diversity jurisdiction to the federal courts could, in theory, be understood to include a grant of lawmaking power. ${ }^{178}$ In the course of hearing common law claims, the federal courts would make the law to apply to those claims. However, the RDA, as interpreted in Erie, rejects that approach. ${ }^{179}$ Rather than authorizing federal courts to make substantive law, it directs them to take the applicable state law as they find it.

In Gasperini, the Court behaved as if it were trapped between the RDA's command that it follow the state's substantive policy and the Seventh Amendment's demand to respect the jury's verdict. In a conflict between a state statute and the Constitution, it is clear which one prevails. Nonetheless, the Court responded to the force of Erie policy by seeking out a resolution that would enforce state policy without offending the Seventh Amendment, perhaps distorting its Seventh Amendment analysis to get there. ${ }^{180}$ The RDA, however, says that the federal courts should follow state law, where it applies, not that they should devise new laws in order to serve the policy goals they believe to have been articulated by the states. The Court's freelancing in Gasperini took it exactly where Erie meant it should not go: rather than simply apply state law, the Court had to discern what policies New York legislators meant to pursue, balance those

\footnotetext{
${ }^{177}$ Erie R.R. v. Tompkins, 304 U.S. 64, 78 (1938).

178 See Martha A. Field, Sources of Law: The Scope of Federal Common Law, 99 HARV. L. REV. 881, 915-16 (1986) (noting this possibility and its rejection in Erie); Jay Tidmarsh \& Brian J. Murray, A Theory of Federal Common Law, 100 Nw. U. L. REV. 585, 623 (2006) (noting that Semtek involved federal common lawmaking based solely on the existence of diversity jurisdiction).

179 See Field, supra note 169, at 915-16.

${ }^{180}$ See LAURENCE H. TRIBE, AMERICAN CONSTITUTIONAL LAW 629 (2000) (sharply criticizing Gasperini's treatment of the Seventh Amendment, calling it "aberrant" and not worthy of deference as a matter of stare decisis).
} 
state policies with federal interests, and devise a practice that the Court believed would appropriately accommodate those interests. ${ }^{181}$

Like in Semtek, in Gasperini the Court took upon itself the authority to formulate the law that would apply to a diversity case. In Semtek, the Court appears to have done so on the basis of its inherent powers. As shown in Part II.A., however, inherent powers were unavailable in light of the Court's rationale for rejecting the applicability of Rule 41(b). In Gasperini, the Court did not explain why it could develop policy to accommodate state interests, rather than simply apply (or not apply) state law. The RDA rejects such a role for the federal courts in diversity. In both Semtek and Gasperini, the Court's approache was justified in the name of accommodating state substantive policy but resulted in discretionary, policy-making authority accruing in the federal courts. ${ }^{182}$

\section{The REA and the Scope of State Legislative Authority}

In Semtek and Gasperini, the Supreme Court seemed to see itself as serving the goals of Erie and the RDA by accommodating state law, yet retaining federal supremacy where necessary. In this Part, I argue that the Court's good intentions toward the states were misplaced. Its efforts to forge creative compromises between state and federal practices greatly magnify judicial discretion, which is contrary to both the federalism and the separation of powers aspects of Erie and the REA. Moreover, the Court's justification for increasing its own discretion-greater accommodation of state lawis flawed. Paradoxically, federalism and respect for state authority over substantive law could be equally well served by a wholesale

\footnotetext{
${ }^{181}$ As noted above, this description of Gasperini is based on the summary paragraph at the beginning of the opinion and the presentation of the case in most commentary. See supra note 77. A better approach, which the Court mya have had in mind but which it did not clearly express, is described infra, Part III.C.

${ }^{182}$ See generally Laura E. Little, Empowerment Through Restraint: Reverse Preemption or Hybrid Lawmaking, 59 CASE WESTERN L. REV. _ (forthcoming 2011) (draft on file) (demonstrating that apparent deference to state law can "empower a strong federal judiciary" and highlighting the opportunities thereby created for hybrid lawmaking, especially the incorporation of principles of international law).
} 
approach that adheres to valid federal Rules regardless of the states' idiosyncratic use of procedure to serve substantive goals. This is so because a uniformly applied set of Federal Rules would put state lawmakers on notice of the procedures to be used in diversity cases and allow them to formulate their substantive law accordingly. This approach would have the beneficial effect of increasing democratic transparency in the states.

\section{Echoes of the First Two Phases}

The Court's choice-of-law decisions in Phase Three echo some of the themes from Phases One and Two, and are thus subject to the same critiques. While Phase Two had its excesses, its conceptual framework was sound; part of the problem with Phase Three is the re-introduction of mistakes from Phase One. The Court should abandon these mistakes and return to a moderated version of Phase Two.

Before Hanna, the Supreme Court inaugurated the practice of adopting implausibly narrow readings of Federal Rules in order to apply state law instead. ${ }^{183}$ This practice has returned in Phase Three. ${ }^{184}$ The practice is especially pernicious when a more natural reading of the Rule continues to be applied in federal question cases, so that the same language in the same Rule means two different things, depending on the basis for federal jurisdiction. Even Justice Stevens's "retail" approach in Shady Grove would be an improvement, if it entailed frank acknowledgement that the Rule was being found invalid as-applied, rather than disingenuously distorted. $^{185}$

This conceptual improvement, however, would not solve the problem of excessive discretion by the federal courts. The retail approach means having federal judges decide in every case whether a state's true motive for its law is substantive or procedural, a more

${ }^{183}$ See, e.g., Ragan v. Merchants Transfer \& Warehouse Co., 337 U.S. 530 (1949).

${ }^{184}$ See supra, parts I.C.2 and I.C.3 (discussing Semtek and Shady Grove).

${ }^{185}$ See Shady Grove Orthopedic Assoc. v. Allstate Insur. Co., _ U.S. _, 130 S.Ct. 1431, 1448 (2010) (Stevens, J., concurring in part and concurring in the judgment). 
difficult task than the already-difficult one of classifying an actual rule or law as such. Each case would also involve a Byrd-like weighing of the strength of those state interests, as compared to any federal interests at stake. ${ }^{186}$ In contrast, the approach of the Shady Grove plurality could mark the end of Phase Three and a return to the conceptual structure of Phase Two, although ideally with a less aggressive approach to defining the sweep of Federal Rules. As discussed below, this return would best be served by taking the wholesale, rather than the retail, approach to the Rules themselves.

\section{Separating Substance and Procedure to Improve State Lawmaking}

While Phase Two may have gone too far, it was conceptually the right approach, and the Shady Grove plurality is right about how the validity of Rules should be evaluated. Many of the pros and cons of the "wholesale" and "retail" approaches have been debated elsewhere. ${ }^{187}$ Here, I focus on one argument for the "wholesale" approach that has been neglected and that directly answers one of the main concerns of those on the "retail" side.

A primary theoretical argument on the retail side is respect for democratic enactments in the states. In this section, I show that adhering to federal procedures can be beneficial to state-level democracy, because it forces state lawmakers to make their policy preferences clear through the substantive law, rather than masking preferences through specialized procedure. This justification for wholesale, rather than retail, federal procedure gains support from the observations of several theorists who have, from a variety of

\footnotetext{
${ }^{186}$ This is not to say that Byrd should be abandoned in the unguided Erie context, or that Byrd-like concerns cannot be relevant even in the REA context. See Freer \& Arthur, supra note 34, at 102 (arguing that the policies reflected in Byrd pervade both RDA and REA analysis). Rather, it is to suggest that federal courts should not have to engage in Byrd-like balancing every time they apply a Federal Rule in a diversity case, where local practice would differ.

${ }^{187}$ See Ely, supra note 1, at 733-34 (outlining and endorsing the retail approach); Shady Grove, 130 S.Ct. at 1440-47 (endorsing the wholesale approach and criticizing the retail approach used by the dissent and concurrence).
} 
perspectives, analyzed the relationship between substance and procedure in light of democratic norms. ${ }^{188}$ Moreover, at least in recent years, this justification is consistent with congressional action manifesting a desire to maintain the federal courts as a procedurally independent forum for litigating state law claims. ${ }^{189}$

A wholesale approach to the Federal Rules has the potential to improve state lawmaking by forcing state lawmakers to be more open and transparent with respect to substantive goals. The fact that state law claims will be adjudicated under federal procedures reduces the ability of state lawmakers to say, with Representative Dingell, "“I'll let you write the substance ... you let me write the procedure, and I'll screw you every time." 190 Dingell's statement reflects the fact that a substantive goal can easily be undermined by imposing procedural hurdles. Substantive entitlements are visible to the public when it assesses the government's work, while procedural mechanisms are more arcane, difficult to understand, and usually trans-substantive. When lawmakers tinker with procedure on a substance-specific basis, they often do so in order to modify substantive rights de facto, even if the substantive right remains formally unchanged.

Many will regard the lawmaker's ability to fine-tune substantive rights through procedural mechanisms as a good thing. Legislatures retain ultimate control over many aspects of procedure in part because of the close connection between substance and procedure.

188 See infra, text accompanying notes 182-206.

${ }_{189}$ See infra, text accompanying notes $217-20$.

${ }^{190}$ Regulatory Reform Act: Hearing on H.R. 2327. Before the Subcomm. on Admin. Law and Governmental Regulations of the House Comm. on the Judiciary, 98th Cong. 312 (1983) (statement of Rep. John Dingell). In many states, state lawmakers may be less sophisticated than Congress in their ability to manipulate substance through procedure. Many state legislatures are part0time and lack the staff and other resources to carry through on a boast like Representative Dingell's. That reality, however, strengthens the argument made in the text. State legislators who lack such resources are more vulnerable to the influence of lobbying and may support seemingly innocuous procedural reforms without realizing their substantive effects. The lawmakers themselves may be in the same position as the general public when it comes to the opaqueness of procedure. 
Indeed, the notion of a dichotomy between the two categories is relatively recent. ${ }^{191}$ Nonetheless, that dichotomy now lies at the root of the litigation framework that has been created by Congress and that is contemplated by diversity jurisdiction, the RDA as interpreted in Erie and its progeny, and the REA. My argument here is that dichotomy is not necessarily a usurpation of state legislative prerogatives but instead can enhance the democratic legitimacy of state substantive law. While substance and procedure may be inextricably intertwined, there is still value in trying to separate them.

Other commentators have argued that separating substance from procedure can promote democratic values. ${ }^{192}$ Their analyses have focused on concerns that some of the Federal Rules are "too substantive" and thus improperly alter substantive rights under state and federal law alike. ${ }^{193}$ This Article takes no position on where the substance-procedure line should be drawn for purposes of the REA, except that the line should be drawn wholesale rather than retail. However, the democratic problems created by an over-reaching judiciary that uses procedure improperly to affect substance are similar in kind to those of a legislature that does the same. The same theoretical points thus support the idea that adherence to the Federal Rules in federal court is no insult to the democratic processes or lawmaking authority of the states.

Martin Redish's work contains the most explicit and extensive discussion of the democratic implications of manipulating procedure in order to affect substance in the context of purely federal law. ${ }^{194}$

\footnotetext{
191 Thomas O. Main, The Procedural Foundation of Substantive Law, 87 WASH. U. L. REV. 801, 804-10 (2010) (describing how the concept of substance and procedure as a dichotomy emerged along with the convergence of law and equity and coincided with the early development of courts in the United States).

${ }^{192}$ See infra, text accompanying notes 194-208, 212-18 (discussing work by Martin Redish and JoEllen Lind).

${ }^{193}$ See, e.g., Martin H. Redish, Class Actions and the Democratic Difficulty: Rethinking the Intersection of Private Litigation and Public Goals, 2003 U. CHI. L. F. 71 (hereinafter Redish, Class Actions); Lind, supra note 28.

${ }^{194}$ See Redish, Class Actions, supra note 181; Martin H. Redish \& Christopher R. Pudelski, Legislative Deception, Separation of Powers, and the Democratic
} 
Redish argues that a legislature has a duty to be forthright about the substantive rights it enacts into law. As part of that duty, the legislature cannot create opaque procedural requirements that in effect undermine the rights proclaimed by the substantive law:

For example, in formally adopting "standard A" as a general rule of decision, while simultaneously requiring the federal courts to reach decisions that effectively amount to adoption of "standard B" or "standard "not A," Congress has substantially subverted the representational democratic process. ${ }^{195}$

Redish argues that this sort of legislative deception could violate both the procedural due process rights of litigants and the separation of powers. ${ }^{196}$

An example where procedural rights might be violated is Title VII of the Civil Rights Act. Deborah Brake and Joanna Grossman have demonstrated that the remedial scheme established under Title VII is so burdensome on claimants, so unforgiving about its short deadlines, and so poorly designed as a response to the reallife experience of discrimination, that Congress has failed to protect the substantive rights purportedly created by Title VII. ${ }^{197}$ While Congress may not have been under a duty to create those substantive rights, it claims to have created them and reaps the political benefit of having done so. If it has encumbered those substantive rights with such a defective enforcement mechanism that they effectively do not

Process: Harnessing the Political Theory of United States v. Klein, 100 Nw. U. L. REV. 437 (2006) (hereinafter Redish \& Pudelski, Legislative Deception); Martin H. Redish, Federal Judicial Independence: Constitutional and Political Perspectives, 46 MERCER L. REV. 697 (1995) (hereinafter Redish, Federal Judicial Independence).

${ }^{195}$ Redish, Federal Judicial Independence, supra note 194, at 715-16.

${ }^{196}$ Redish, Federal Judicial Independence, supra note 194, at 716.

${ }^{197}$ Deborah L. Brake \& Joanna L. Grossman, The Failure of Title VII as a RightsClaiming System, 86 N.C. L. Rev. 859 (2008). That Brake \& Grossman's thesis is an example of Redish's point is pointed out in Howard M. Wasserman, Jurisdiction, Merits, and Procedure: Thoughts on a Trichotomy, 102 NW. U. L. REV. 1547, 1557-58 (2008). 
exist for a substantial portion of people, then perhaps, under Redish's theory, Congress has violated the due process clause by purporting to create a substantive right but then making it overly burdensome to vindicate that right.

Separation of powers is a more salient concern when Congress forces the courts to employ Orwellian double-speak. Redish, with Christopher Pudelski, argues that the Supreme Court implicitly recognized this problem in United States v. Klein. ${ }^{198}$ Klein involved the ability of southerners to reclaim property lost during the Civil War. ${ }^{199}$ To prevail, a claimant had to have remained loyal to the United States. ${ }^{200}$ The Supreme Court had held that receipt of a presidential pardon constituted proof of loyalty. ${ }^{201}$ Congress had sought to reverse that presumption, declaring that a pardon should instead be taken as proof of disloyalty. ${ }^{202}$ In Klein, the Supreme Court struck down the presumption, but the precise reason for doing so is not clear from the opinion. The statute drew into question not only the independence of the judiciary in determining the evidentiary significance of a particular fact but also the scope of the president's pardon power. ${ }^{203}$ Redish and Pudelski make a convincing argument that concerns about legislative deception were part of the mix. ${ }^{204}$ Redish has argued that the same concerns should have led to a different outcome in Michael H. v. Gerald G., in which the Supreme Court upheld California's marital presumption of paternity, rejecting the parental claims of the genetic father in favor of the mother's husband. ${ }^{205}$ Having promised the public that "loyal" southerners would reclaim their property and that "fathers" would have legal rights as parents, the legislature could not require the courts to make a mockery of language by following presumptions that forced the opposite conclusions. Redish argues, "Under separation-of-powers

19880 U.S. (13 Wall.) 128 (1872), discussed in Redish \& Pudelski, Legislative Deception, supra note 194.

${ }^{199}$ Klein, 80 U.S. at 135.

${ }^{200}$ Klein, 80 U.S. at 137.

${ }^{201}$ Klein, 80 U.S. at $143-44$.

${ }^{202}$ Klein, 80 U.S. at 145.

${ }^{203}$ Klein, 80 U.S. at 148.

${ }^{204}$ Redish\& Pudelski, Legislative Deception, supra note 194, at 447-51.

${ }^{205}$ Redish, Federal Judicial Independence, supra note 194, at 716-17. 
principles, this congressional action is defective, because it effectively enlists the federal judiciary in a scheme to bring about voter confusion." 206

Redish's argument is a difficult one where the deceptive procedural requirement is created by the same legislature that has power over the substantive law. Even opaque procedural statutes are public and open to inspection. And lawyers, at least, are accustomed to the occasional counter-intuitive presumption or definition. If "substance" and "procedure" are merely labels that attach to conclusions, why not "father" and "loyal"? Moreover, in each of Redish's examples, the legislative presumption is reasonably defensible. Pardons are usually granted to people who have, in fact, done something wrong, and an admission of guilt is sometimes required. Congress may have been justifiably outraged that pardons were being used to deem people "loyal" for purposes of its compensation scheme. Similarly, marriage to a child's mother has historically been the crux of legal and social fatherhood. ${ }^{207}$ The marital presumption in Michael $H$. could be mocked only because of fairly recent technology allowing for the identification of a genetic father. It is difficult to know when a legislative presumption would become so absurd that it would violate the separation of powers to force the courts to speak in the legislature's terms.

Redish acknowledges that it would be difficult to say when a procedural statute goes so far in deceiving the public about the substantive content of the law that a court should strike it down. ${ }^{208}$ For purposes of my claim, however, that line need not be drawn. I do

\footnotetext{
${ }^{206}$ Redish, Federal Judicial Independence, supra note 194, at 716.

${ }^{207}$ Nancy E. Dowd, From Genes, Marriage and Money to Nurture: Redefining Fatherhood, 10 CARDOZO WOMEN's L.J. 132, 132 (2003) ("Largely in the name of gender equality and to some extent in the name of children's rights, we have moved from a legal definition of fatherhood linked to marriage towards a legal definition of fatherhood linked to genes.").

${ }^{208}$ Redish\& Pudelski, Legislative Deception, supra note 194, at 457-58 (describing five difficult questions about the model of legislative deception, including " $[\mathrm{I}] \mathrm{f}$ it is conceded that all procedural and evidentiary rules may in some sense impact the substantive rights being enforced, why disapprove of such a connection only in certain contexts?").
} 
not suggest that state laws be struck down as unconstitutional for intermingling substance and procedure. Rather, I argue that federal courts should recognize that adhering to a uniform system of federal procedure can benefit democratic process in the states, even when displacing state procedure affects substantive outcomes. Protecting procedure from the legislature prevents lawmakers from engaging in the sort of deception that Redish criticizes.

In a similar vein, Linda Mullenix has argued that maintaining independent procedures Is necessary for a well-functioning independent judiciary. ${ }^{209}$ Her focus was on Congress's increasingly frequent interventions in federal procedure in the last thirty years. ${ }^{210}$ Mullenix decries the resulting politicization of federal procedure as it is created through legislative rather than judicial institutions. ${ }^{211}$ The same phenomenon can occur at the state level. If it does, state courts, drawing on either Redish's or Mullenix's ideas, might decide that their prerogatives have been invaded and strike down excessive legislative interference with procedure as a matter of state separation of powers. Even without such drastic action, however, the existence of federal diversity jurisdiction can check the ability of state legislators to manipulate substance through procedure.

Redish's theory described above is concerned with legislators using procedure to subvert substance. Redish and others have also expressed concern about judges doing the same thing. ${ }^{212}$ JoEllen Lind terms this phenomenon "procedural Swift" and accuses the federal courts, jointly with Congress, of manipulating procedure to undermine state substantive law. ${ }^{213}$ Redish has also argued that

\footnotetext{
${ }^{209}$ Linda M. Mullenix, Judicial Power and the REA, 46 MERCER L. REV. 733, 734 (1995) ("A judiciary that cannot create its own procedural rules is not an independent judiciary.").

${ }^{210}$ Mullenix, supra note 209, at 735-36.

${ }^{211}$ Mullenix, supra note 209, at 754-55.

${ }^{212}$ See, e.g., Redish, Federal Judicial Independence, supra note 194; Lind, supra note 28; Lear, supra note 159, at 1152 ("This Article takes the position that the Court must abandon the forum non conveniens doctrine as an unconstitutional usurpation of congressional power.").

${ }^{213}$ Lind, supra note 28, at 719 ("Procedural Swift ... is the strategy of creating federal tort law through the guise of regulating procedure.").
} 
courts wrongly use procedure to transform substantive law. ${ }^{214}$ Interestingly, Lind and Redish both point to class action procedure as a prime example, but with opposite perspectives. Lind argues that the Class Action Fairness Act of $2005^{215}$ and stringent federal standards for certification permit defendants to remove to federal court and thereby avoid legitimate enforcement of state law through class mechanisms. ${ }^{216}$ Congress, she argues, should not "use complex litigation to hide law reform that could not gain public approval if its consequences were better known." ${ }^{, 217}$ Redish, in contrast, argues that the judicial invention and liberalization of class actions to make certain claims feasible that would not otherwise be brought is an illegitimate departure from legislative expectations. ${ }^{218}$

This difference between Lind and Redish on class actions is a matter of baselines. As David Shapiro has pointed out, the availability or non-availability of class actions affects enforcement of substantive law, but this fact does not tell us what the default rule should be. ${ }^{219}$ More generally, Thomas Main argues that substantive law is always premised on the procedural system that legislators assume will be used to enforce it. ${ }^{220}$ Any change in procedures will affect the balance of deterrence contemplated when the law was enacted. ${ }^{221}$ Main concludes with two proposed solutions to the problem of "mismatch" between procedures when a court applies

${ }^{214}$ See Redish, Class Actions, supra note 193.

${ }^{215}$ Pub. L. No. 109-2, 119 Stat. 4 (2005) (making several changes to class action procedure, including provisions making it much easier for defendants to remove large class actions to federal court).

${ }^{216}$ See Lind, supra note 28, at 754 (suggesting that the goal of various federal procedural reforms "is to curtail mass tort class actions altogether by redirecting them to the federal forum where they will be obstructed so profoundly that defendants' overall liability will be reduced.").

${ }^{217}$ Lind, supra note 28 at 719.

${ }^{218}$ Redish, Class Actions, supra note 193, at 73-74.

${ }^{219}$ David L. Shapiro, Class Actions: The Class as Party and Client, 73 NOTRE DAME L. REV. 913, 957 (1998) ("[E]ven one who takes a broader view than I do of the scope of judicial rulemaking power should, I believe, balk at the use of that power either to endorse or to reject the entity theory [of class actions] advanced here.").

${ }^{220}$ Main, supra note 191.

${ }^{221}$ Main, supra note 191 at 823-25. 
foreign law. First, when a court applies foreign law, it should apply as much of foreign law, both substantive and procedural, as possible; legislatures, in turn, should intermingle substance with specially tailored procedure to a greater extent than they do now. Second, at the policy level, we should strive to harmonize procedure across jurisdictions. $^{222}$

In the domestic choice-of-law context in federal courts, both administrative and theoretical considerations favor Main's second solution over his first. Administratively, federal courts should not be required to adopt large chunks of the procedural devices of the fifty states while simultaneously operating under the uniform federal rules. Moreover, procedure changes over time, and fidelity to Main's goal of fulfilling legislative expectations would require courts to discover and apply the procedures that existed at the time each substantive rule was adopted. Theoretically, as discussed above, uniform procedure requires legislatures to pursue their substantive goals more transparently.

In addition, Main's claim that changes in procedure wrongly interfere with legislative expectations rests heavily on a deterrence theory of lawmaking. ${ }^{223}$ While many lawmakers may operate from that perspective, the public may expect the substantive law to mean what it says in every case, not just as a matter of probabilities and enforcement rates. Only people who have been through at least one year of law school are likely to be comfortable answering the question "Isn't that illegal?" with "Yes, but nothing is meant to be done about it."

The approach advocated here puts some burden on state lawmakers to be familiar with judicial procedures and perhaps even to amend substantive law occasionally to keep pace with evolving procedural law. As long as we are satisfied that "procedural law," as embodied in the Federal Rules and in the courts' use of inherent

\footnotetext{
${ }^{222}$ Main, supra note 191 at $838-40$. Main also advises courts to be humble and skeptical about their ability to apply foreign law. Id. at 838 .

${ }^{223}$ See Main, supra note 191, at 823-25 (describing legislation as calibrated to achieve a particular level of deterrence).
} 
authority, is sufficiently procedural, this is not too much to ask of legislators. Congress unquestionably has the power to determine federal procedure and to confer diversity jurisdiction. ${ }^{224} \mathrm{By}$ following uniform, trans-substantive procedure, the federal courts may deprive state lawmakers of the ability to modify their own substantive creations through substance-specific procedures. Democratic theory suggests that this result may not be a bad thing.

Consider the contrary assumption that has animated the Supreme Court's jurisprudence in Phase Three. In Gasperini, the Court seemed almost to feel guilty about the existence of the Seventh Amendment as a constraint on federal courts. ${ }^{225}$ It reasoned as if state legislators enact their laws in a state-only bubble and the entire burden of figuring out how to carry out their wishes in diversity cases must fall on the federal courts. State legislators, however, should be assumed to be aware of diversity jurisdiction, and there is nothing wrong with expecting them to take it into account. If Congress had considered a statute similar to the New York law at issue in Gasperini, the Seventh Amendment would surely have been a topic of discussion; New York legislators should have had the same conversation.

Consider also the state laws at issue in Shady Grove. The substantive law proclaimed that insurance companies would be liable for a two percent penalty if they failed to pay claims in a timely fashion. ${ }^{226}$ Perhaps, when this law was enacted, legislators and insurers alike knew that it would rarely be enforced: the cost of litigation would outweigh the potential recovery in individual actions, and the state prohibition on penalty class actions would prevent aggregation. ${ }^{227}$ The availability of class actions in federal

\footnotetext{
${ }^{224}$ Erie R.R. v. Tompkins, 304 U.S. 64, 91-92 (1938) (Reed, J., concurring in part and concurring in the result) (" $[\mathrm{N}] \mathrm{o}$ one doubts federal power over procedure.").

${ }^{225}$ See supra, part I.C.1 (describing the Supreme Court's accommodation of state law in Gasperini).

${ }^{226}$ Shady Grove Orthopedic Assoc. v. Allstate Insur. Co., _ U.S. _, 130 S.Ct. 1431, 1436 (2010).

${ }^{227} C f$. Main, supra note 191, at 823-25 (arguing that legislators enact substantive law against a backdrop of procedures they assume will apply).
} 
court changes that, leading to far more efficient enforcement of the substantive right proclaimed on the face of the statute. Now, perhaps, as a matter of regulatory policy, this outcome over-deters: it makes insurance companies rush their payments too much, or it imposes liability out of proportion to their moral culpability, or it makes too many campaign contributors unhappy. If that is so, the legislature should change the substantive law. This outcome is preferable to keeping the same law-promising ordinary citizens that they are protected by this penalty-but disabling the courts from enforcing it. If the legislature says that insurance companies should pay two percent penalties, courts are entitled to assume that the legislature actually wants this to happen. They should adopt procedures that achieve this result in as "just, speedy, and inexpensive" a fashion as possible. ${ }^{228}$ Separating substance from procedure, artificial as it may be in some senses, has the virtue of requiring the legislature to speak as clearly as possible in the substantive law.

This separation of substance and procedure is also consistent with congressional action from the REA to the present. Although Congress initially recognized the importance of state substantive law by enacting the RDA, since 1938 it has regularly expressed a preference for independent federal procedure. ${ }^{229}$ That preference has become so pronounced in a recent years that it prompted Geoffrey Hazard to ask, "Has the Erie doctrine been repealed by Congress?" 230 Hazard argues that the judicial system envisioned by Congress is best described as follows:

State law is the substantive basis of the American legal system, displaced only selectively by federal substantive law. The federal court system, however, provides the premier American model of the judiciary and, as such, is

\footnotetext{
${ }^{228}$ Fed. R. Civ. Proc. 1.

${ }^{229}$ Hazard, supra note 125, at 1639 (describing a "long history of interaction between state and federal courts in which different procedures have applied and in which federal procedure has often trumped that of the state").

${ }^{230}$ Hazard, supra note 125 , at 1629 (title).
} 
called upon to administer its form of justice in legal disputes. $^{231}$

In statutes like the Class Action Fairness Act, Congress has expressed its view that, "in certain types of cases, the judicious administration of state law is better entrusted to federal courts."

The dichotomy between substance and procedure may be artificial and thus difficult to define and maintain. It is nonetheless a dichotomy that Congress has placed at the foundation of the federal judicial system and that serves important functions in that system. In Erie's Third Phase, a shifting plurality of the Supreme Court has begun to break down that dichotomy, apparently in the name of state democratic processes. State-level democracy, however, does not need this solicitude. Just as the courts are frequently at pains to ascertain and apply state substantive law, state lawmakers can reasonably be expected to ascertain federal procedural law, and to plan accordingly. If they do so, uniform federal procedure will not stand in the way of their substantive goals. Moreover, state law would gain in democratic legitimacy and transparency because lawmakers would be prevented from manipulating procedure in ways that undermine the apparent goals of substantive law.

\section{ENDING PHASE THREE}

Phase Three of Erie is characterized by discretionary lawmaking by the federal courts. This discretion is claimed for the seemingly self-effacing purpose of accommodating state policies. As it turns out, however, state-level lawmaking would likely fare just as well or better in the face of uniform federal procedure. Fortunately, Phase Three is so far strictly a Supreme Court phenomenon, and the decisions in Gasperini and Semtek can and should be contained. This section sketches a plan for construing those cases narrowly and bringing an end to Phase Three of Erie.

\footnotetext{
${ }^{231}$ Hazard, supra note 125 , at 1630.

${ }^{232}$ Hazard, supra note 125, at 1629; see supra, note 203 (describing the Class Action Fairness Act).
} 


\section{A. The Third Phase Has No Traction in the Lower Courts}

Lower federal courts have routinely cited Gasperini and Semtek as the Supreme Court's most recent articulation of Erie principles. The lower courts have not, however, emulated the Supreme Court's Phase-Three approach by creating their own accommodations of state policy. Instead, they have continued to give "yes" or "no" answers to Erie questions. Phase Three can therefore be contained, as a Supreme Court frolic that has not yet taken root in general federal practice.

Lower courts are presumably more sensitive than the Supreme Court to the dangers of inviting litigants not only to argue for or against the application of state law but also to suggest novel accommodations of the interests embodied in each. Perhaps for this reason, I have found only one lower court decision that even considered following the Phase Three strategy. In Houben v. Telular, the Seventh Circuit reviewed the leading Erie cases in detail and then commented, "It seems possible to us, in light of the substantive policy ... and in keeping with Gasperini's approach, that state substantive interests and federal procedural rules might be capable of accommodation." 233 After a short discussion of that possibility, however, the court concluded that the accommodation was "too much of a strain" and decided not to apply state law at all. ${ }^{234}$ This reluctance to follow the Gasperini path bodes well for ending the Third Phase before it takes hold beyond the Supreme Court.

\section{B. Containing Semtek}

In Semtek, the Supreme Court may have had a legitimate reason for creating federal common law based on its inherent power over procedure in the federal courts. The Court, however, was not transparent about how it got there. The best way of limiting its effect in the future is to confine its holding to the particular circumstances of the case- the preclusive effect of a dismissal on statute-of-

\footnotetext{
${ }^{233}$ Houben v. Telular Corp., 309 F.3d 1028, 1038 (7th Cir. 2002).

${ }^{234}$ Houben, 309 F.3d at 1039.
} 
limitations grounds - rather than to construe it as a general statement about preclusion.

The most serious difficulty posed by Semtek was its suggestion that preclusion is, as a general matter, a substantive realm that is beyond the reach of the REA. ${ }^{235}$ Other Federal Rules regulate matters that bear on preclusion, such as permissive and compulsory joinder. ${ }^{236}$ If read to deal generally with preclusion, Semtek calls into question the validity of those Rules as they are generally understood and applied. ${ }^{237}$ Instead, Semtek should be construed as primarily a statute of limitations case, rather than a preclusion case. At the next opportunity, the Court could clarify that matters such as joinder, including the preclusive effects of failing to join a compulsory claim, are within the scope of the REA.

While this approach is, admittedly, not the best reading of the Semtek decision, it is at least plausible. Patrick Woolley has already shown how to "save" federal preclusion rules from Semtek using the back door that the Court left open for ensuring the preclusive effect of dismissal as a sanction. ${ }^{238}$ Recall Semtek's holding: the preclusive effect of a diversity judgment is governed by federal common law; to determine the content of that federal common law, courts should borrow from the preclusion law of the forum state, unless federal interests demand a different rule. ${ }^{239}$ The stated reason for the final caveat was the remote possibility of a state failing to accord preclusive effect to dismissals that sanction a party. ${ }^{240}$ Woolley, however, points out that strong federal interests are also at stake in a

\footnotetext{
${ }^{235}$ Semtek Int'1 Inc. v. Lockheed Martin Corp., 531 U.S. 497 (2001).

${ }^{236}$ See Fed. R. Civ. Proc. 13.

${ }^{237}$ See Dudley \& Rutherglen, supra note 10, at 724 (Semtek "preserves the validity of Rule 41(b), but only at the expense of casting doubt on other Federal Rules, notably Rule 13(a) on compulsory counterclaims and Rule 23 on class actions, which presumably determine the preclusive effect of any resulting judgment."); but see Burbank \& Wolff, Redeeming, supra note 99, at 50 (stating that Rule 13 could "be used to support the application of federal common law of preclusion" only if "justified by its non-preclusion policies").

${ }^{238}$ Woolley, supra note 90.

${ }^{239}$ Semtek, 531 U.S. at 508-09.

${ }^{240}$ Semtek, 531 U.S. at 509.
} 
variety of other aspects of the preclusion analysis, such as joinder, whether claims are compulsory, and when a judgment becomes final. ${ }^{241}$ Again, all of these federal interests are procedural interests, properly governed through the REA and/or the inherent powers of the courts. In Woolley's assessment, only statutes of limitations and questions of privity fail to trigger sufficient federal interests to warrant uniform federal treatment. ${ }^{242}$

This re-reading of Semtek remains possible because the Semtek Court did not firmly commit itself to the position that Rule 41(b) would be invalid if construed to have preclusive effect. ${ }^{243}$ Its suggestion of that possibility should be read in the context of a statute of limitations analysis. Statutes of limitation have a unique place in Erie jurisprudence. It was a statute of limitations that first drove the Court, in Guaranty Trust, to try to articulate a test for when state law controlled in a diversity case. ${ }^{244}$ Once established, federal respect for state statutes of limitations contributed to the excess of the First Phase in Ragan. ${ }^{245}$ Semtek should be seen as part of this pattern rather than as establishing a general rule for preclusion questions.

Under this approach, Semtek becomes the exception to a general rule that the preclusive effect of a federal judgment is a matter of federal procedural law. Rules of preclusion "really regulate procedure" and are thus properly addressed in the Federal Rules. However, a few aspects of preclusion law-statutes of limitations, perhaps privity—are sufficiently substantive to warrant restrained interpretation of the Rules, and are substantive for Erie purposes, so that state law applies if the Federal Rules do not. Importantly, the conclusion that these issues are substantive is a wholesale, not a

\footnotetext{
${ }^{241}$ Woolley, supra note 90, at 532; see also Erichson, supra note 138, at 1003 (pointing out that "nearly all preclusion rules are transsubstantive").

${ }^{242}$ Woolley, supra note 90, at 529, 532 (arguing that "neither the Erie policy nor the REA prevents recognition of the very strong federal interest in uniform federal rules of preclusion with respect to all but a handful of issues").

${ }^{243}$ See Semtek, 531 U.S. at 506.

${ }^{244}$ Guaranty Trust Co. v. York, 326 U.S. 99 (1945).

${ }^{245}$ Ragan v. Merchants Transfer \& Warehouse Co., 337 U.S. 530 (1949).
} 
retail, determination. One can say that "joinder" is properly deemed procedural and governed by the law of the court that hears the case, while "privity" or "statutes of limitations" are best governed by the law-supplying state without inquiring into what laws any particular state has adopted in these matters. ${ }^{246}$

In the alternative, the Court could adhere to the view suggested in Semtek that preclusion is, in general, too substantive for the REA; perhaps the Court would reach this conclusion in the course of adopting a more rigorous approach to the REA than the "really regulates procedure" test. The problem with Semtek, of course, is that the Supreme Court adhered to that view only for the first half of the opinion. To be consistent, the Court should have refrained from claiming inherent power over a matter it had already cast as too substantive for the REA. The Court therefore should have held that it was bound to follow state preclusion law not by federal common law of its own creation but by the RDA. While I believe it would be preferable to recognize most questions of preclusion as procedural for REA purposes, ${ }^{247}$ what is untenable is for the Court to claim

\footnotetext{
${ }^{246}$ The one major problem not addressed by this reading of Semtek is that even the new reading retains the dual interpretation of Rule 41(b). The Rule means little or nothing in diversity cases but is still understood to govern preclusion in federal question cases. The problem of duel interpretations originated in Phase Two, not in Semtek. One way of dealing with this problem is to distinguish true interpretations of the Rules from judicial "glosses" on the Rules, in which the courts feel in the interstices of the Rules. A true interpretation would govern in a diversity case, but a "gloss" might give way to state law if it were substantive for RDA purposes. See supra, note 39 (discussing this strategy for dealing with the dual interpretation cases). Short of flat-out overruling all the cases in which it has occurred, the best thing that the Court can do is to just stop doing it, as it could have done in Semtek: The most natural way to read Rule 41(b) is as a default rule for determining whether a federal court's judgment was intended to be on the merits. A simple way out of the Semtek problem would have been to hold that the plaintiff should have requested that the judgment be issued "without prejudice" because California law, made applicable through the RDA, required as much. The district court's refusal to do so could have been addressed on direct appeal. The Supreme Court's decision in Semtek acknowledged this possible sequence of events in footnotes but oddly suggested that the plaintiff's failure to pursue the matter on direct appeal required that it be dealt with in the subsequent case, rather than simply being defaulted.

${ }^{247}$ See generally Erichson, supra note 138, at 1002-03 (arguing that the best rule is to apply the preclusion law of the jurisdiction that rendered the original judgment);
} 
inherent procedural power while at the same time declaring the matter beyond the reach of the REA.

\section{Containing Gasperini}

The flaws in Gasperini are easier to confine to the circumstances of that case. The Gasperini Court presented the case as if it could formulate, not merely apply or not apply, New York law. More specifically, the Court indulged two errors in its approach. First, the Gasperini Court forgot the original point of Erie: that state common law rules are, like state statutes, "laws" under the RDA. Second, faced with what it deemed a substantive New York law in conflict with the federal Constitution, the Court should have used ordinary severability analysis (rather than its own discretionary balancing of state and federal interests) to determine what law to apply.

First, the description of Gasperini in Part I.C.1, above, follows the Court and most commentators in describing the issue as whether the New York statute on appellate review of damages applied in federal court. The Supreme Court concluded the statute was sufficiently substantive to warrant application under Erie, but also that it conflicted with the Seventh Amendment obligations of the federal courts. To read the body of the Court's opinion, the Syllabus, and many other synopses of the holding, one would think that the Supreme Court itself came up with the compromise of accommodating state policy by having the trial court, rather than the appellate court, perform the damages review. ${ }^{248}$

Tobias Barrington Wolff, Preclusion in Class Action Litigation, 105 CoLUM. L. REV. 717, 760 (2005) (explaining that the rendering court can have great influence on future preclusive application of its judgment, even thought it cannot it purport to declare the judgment's applicability to future hypothetical cases).

${ }^{248}$ Gasperini v. Ctr. for Humanities, 518 U.S. 415, 419 (1996) (majority opinion) (holding that "New York's law ... can be given effect without detriment to the Seventh Amendment, is the review standard set out in CPLR $\S 5501$ (c) is applied by the federal trial court judge"); id. at 415 (Syllabus by the clerk of court) (stating the same); Dudley \& Rutherglen, supra note 10, at 707. 
The problem with this description is that not one but two New York laws were relevant in Gasperini. The first was the statute, which required damages review by appellate courts. ${ }^{249}$ Second, as the Court briefly acknowledged in its background section but then ignored for the rest of the opinion, the common law of New York required damages review by trial courts under the same standard. ${ }^{250}$ Erie says that both the statute and the common law are "laws." 251 While the New York statute conflicted with the Seventh Amendment and therefore could not apply in federal court, the common law did not conflict with the Seventh Amendment and could therefore apply. ${ }^{252}$ There was no need for creativity, accommodation, or other interest-balancing by the Supreme Court.

Unfortunately, the Gasperini Court ignored the state's common law rule and treated only the statute as "law" that might apply in federal court. ${ }^{253}$ This raises the question: what if the common law rule had been different? That is, New York must have some legal standard for when a trial court can revise a jury verdict. ${ }^{254}$ If that standard had happened to differ from the standard prescribed by statute for appellate courts, the Supreme Court's freelancing on how to "accommodate" the statute would have ended up paradoxically displacing another state law. Gasperini did not call for the Supreme Court to make up a federal common law of New York damages because New York already had a common law of damages.

\footnotetext{
${ }^{249}$ Gasperini, 518 U.S. at 423 n. 4 (quoting the statute).

${ }^{250}$ Gasperini, 518 U.S. at 425 (noting that the "deviates materially" standard, as construed by New York's courts, instructs state trial judges as well). Whether this rule is considered pure common law or a judicial expansion of the statute, the fact remains that the Supreme Court's analysis ignored the judicial opinions as a controlling source of state law.

${ }^{251}$ Erie R.R. v. Tompkins, 304 U.S. 64, 77-78 (1938).

${ }^{252}$ Gasperini, 518 U.S. at 431-33.

${ }^{253}$ Gasperini, 518 U.S. at 426-31 (discussing the case as if only the statutory direction to appellate courts were at issue).

${ }^{254}$ See Steinman, Our Class Action Federalism, supra note 28, at 41 (pointing out that there is always state law on point, whether statutory law, case law, or an Erie guess about what the state's highest court would do if presented with the question).
} 
Second, in formulating its own accommodation of the statute, the Supreme Court neglected the ordinary task of a court faced with a law that is constitutional in part. Once the Court determined that the New York statute represented a substantive policy choice under Erie, the next step was to apply the statute. Faced with a Seventh Amendment barrier, it should have done just what a New York court would have done, if the Seventh Amendment had the same effect in state court: asked if the statute was entirely unconstitutional or if some part of it could be saved by a severability analysis. The severability analysis_-under New York severability rules, of course-may well have yielded the resolution that the Court reached on its own. Whether it did or not, the decision would have been better because reached by the ordinary tools of statutory interpretation rather than the Court's own creative process. The correct question was not "What kind of accommodation can we make between state and federal interests?" but "What would a New York court do, faced with this statute and a constitutional barrier to applying it in full?"

An approach that focused on statutory interpretation would also be superior because it would have a better chance of revealing the actual legislative intent, which is likely to bear on the initial classification of the law as substantive or procedural. When legislatures enact tort reform measures that implicate procedure, there is nothing wrong with expecting them to know that state tort cases are litigated in both state and federal courts. New laws must therefore be consistent with federal requirements for there to be a chance that they will be fully enforced. Thus, there was no reason for the Supreme Court to tiptoe around the inconvenient fact of the Seventh Amendment.

There is nothing incongruous about the New York statute producing different review procedures in state and federal cases. That difference is a function not of the substance/procedure distinction but of the Seventh Amendment's status as one of a very few unincorporated rights. ${ }^{255}$ The

\footnotetext{
${ }^{255}$ Most provisions of the first eight amendments to the federal Constitution are incorporated against the states through the due process clause of the Fourteenth Amendment. The restrictions on appellate review of jury verdicts that were at issue in Gasperini are among the few exceptions. See Morris B. Hoffman, The Court
} Says No to “Incorporation Rebound," 61 BAYLOR L. REV. 818, 831-32 (2009) (reviewing the state of incorporation at that time). 
New York legislature can anticipate the operation of the federal Constitution in federal court just as well as it can anticipate the operation of the state constitution in state court. Although the statute was apparently consistent with New York constitutional requirements, there is nothing wrong with expecting New York legislators to anticipate the Seventh Amendment problems as well. If those legislators believed they were enacting substantive policy that would apply in federal court, they should have accommodated federal constitutional constraints. On the other hand, a severability analysis grounded in legislative intent might have uncovered that the legislature's concern was with excessive or widely varying verdicts in local trials presided over by local, elected judges. There may have been little concern about federal juries under federal judges. Since the Supreme Court saw the statute itself as sounding in both substance and procedure, it would have been worth asking at this point whether the legislature's goal was to change the substantive law applied in all courts or to correct for procedural biases in the state court system. ${ }^{256}$

It is unfortunate that the Court framed Gasperini as if its task were to create a federal common law of New York tort damages. The Court likely would have reached the same result by respecting New York common law as much as it respected the New York statute, or even by performing a severability analysis, but it would have kept the lines of authority clear. State substantive policy should be implemented through state law, properly interpreted, not by unauthorized federal common law.

\section{CONCLUSION}

Semtek and Gasperini each resulted in the unwarranted exercise of federal judicial discretion rather than a straightforward choice between state and federal law. However, the Supreme Court's creative energy on Erie questions has not yet infected the lower

\footnotetext{
${ }^{256}$ Here, I am taking as given the Gasperini Court's conclusion that the New York law at issue was substantive for RDA purposes and that no Federal Rule applied; the Seventh Amendment is the only federal law in play. In the course of attempting to apply a state law conceded to be substantive, it is of course appropriate to consider legislative intent. Doing so does not conflict with taking a wholesale approach to the validity of the Federal Rules.
} 
courts, and both Semtek and Gasperini can still be confined to their fairly narrow circumstances. The split in Shady Grove indicates that the Supreme Court remains poised between two paths: either ending Phase Three and returning to the conceptual structure of Phase Two, or else continuing with Phase Three's pattern of idiosyncratic accommodation of idiosyncratic state policies. This Article has shown that the Phase-Three approach is unnecessary on its own terms. The approach appears to be motivated largely by a sense that special accommodations are necessary to protect substantive state policy interests, the very interests that Erie itself vindicated. This motivation is misplaced. Case-by-case modification of federal procedural law is not necessary to protect state's democratically chosen policies. Rather, uniform federal procedure will allow states to formulate substantive policy with knowledge of the procedures through which that policy will be enforced and will encourage state lawmakers to act openly through the substantive law rather than manipulate outcomes with special procedures. Shady Grove should therefore mark the end of Erie's Third Phase. 